\title{
Genetic Characterization of Shiga Toxin-producing Escherichia coli Strains Isolated from Imported Beef Meat in Malaysia Using Polymerase Chain Reaction Analysis
}

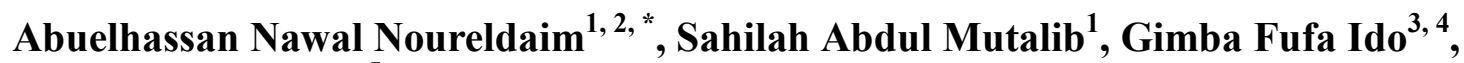 \\ Yusoff Wan Mohtar \\ ${ }^{1}$ Department of Food Science, Faculty of Food Science and Technology, Universiti Kebangsaan Malaysia, Bangi, Malaysia \\ ${ }^{2}$ Department of Animal Genetic Resources, Animal Resources Research Corporation (ARRC)-Animal production Research Khartoum North, \\ Ministry of Animal Resources, Kh artoum, Sudan \\ ${ }^{3}$ Department of Pathology and Microbiology, Faculty of Veterinary Medicine, University Putra Malaysia, Selangor, Malaysia \\ ${ }^{4}$ Avian Influenza Control Project Animal Health Component Desk office, Taraba State Ministry of Agriculture and Natural Resources, \\ Jalingo, Nigeria \\ ${ }^{5}$ Institute Alam Dan Tamdun Melayu, Universiti Kebangsaan Malaysia, Bangi, Malaysia
}

\section{Email address:}

nawalnoureldaim@yahoo.com (A. N. Nouridaim), sahilah.am@gmail.com (S. A. Mutalib), fufagimba@yahoo.com (G. F. Ido), wantar@ukm.my (Y.W. Mohtar)

${ }^{*}$ Corresponding author

\section{To cite this article:}

Abuelhassan Nawal Noureldaim, Sahilah Abdul Mutalib, Gimba Fufa Ido, Yusoff Wan Mohtar. Genetic Characterization of Shiga Toxinproducing Escherichia coli Strains Isolated from Imported Beef Meat in Malaysia Using Polymerase Chain Reaction Analysis. American Journal of Biological and Environmental Statistics. Vol. 5, No. 4, 2019, pp. 52-72. doi: 10.11648/j.ajbes.20190504.11

Received: October 21, 2019; Accepted: November 15, 2019; Published: December 6, 2019

\begin{abstract}
This work was to genetically characterized Shiga toxin-producing Escherichia coli strains isolated from imported beef meat in Malaysia using polymerase chain reaction (PCR) base analysis, seventy four (74) frozen beef meats samples (imported) (n=74) tested originated forty two of the sample were from India and thirty two of the samples were from Australia. The samples were bought from the frozen meat units of five different supermarkets in diverse settings in Malaysia which start from 2012 April to 2013 October on a weekly basis. E. coli and shiga toxin producing E. coli isolation was done Isolation of plasmid was carried out using the PureYield ${ }^{\mathrm{TM}}$ Plasmid Miniprep System. Enterobacterial Repetitive Intergenic Consensus (ERIC) primer was use in genetically isolating the bacteria: We used seven types of primers for Random Amplified Polymorphic DNA-PCR (RAPD-PCR) namely Gen8, Gen9, A1, A7, A10, OPAR8 and OPAR20. Our result revealed that Plasmid profiling showed 16 patterns based on size and 4 patterns on gel. Combination of phenotypically and genotypically approaches revealed a varied heterogeneity among imported beef isolates of $E$. coli. Isolated plasmids from shiga toxin producing E. coli varied in sizes. The sizes are from 4.3 -23.1 kilo base (kb). Sixty two (62) isolates were found to harbor plasmid with size $23.2 \mathrm{~kb}$ while 43 isolates harbored more than a single plasmid. The analysis of data through the use of average linkage (UPGMA, unweight group pair technique with arithmetic averages) using Gel compare 11 software which was displayed in dendrograms, for the, ERIC-PCR and RAPD-PCR (RAPD Gen 8, Gen 9), (Opar 8 and Opar 20), (RAPD A1, RAPD A7and RAPD A10) analysis, produced various cluster. The PCR analysis using OPAR 8 and OPAR 20 also produces various clusters.
\end{abstract}

Keywords: Genetic Characterization, Shiga Toxin-producing Escherichia coli, Imported Beef Meat, Polymerase Chain Reaction (PCR) and Malaysia

\section{Introduction}

Pathogenic bacteria identification was formally through traditional isolation of the bacteria and studying it phenotypically via culture, biochemical analysis and Gram 
staining which were the gold standards for identifying pathogenic bacteria [1]. With the discovery of polymerase chain reaction (PCR) and DNA sequencing, several bacteria genome have been completely sequenced. Comparing the genomic sequences of different bacterial species revealed that $16 \mathrm{~S}$ ribosomal RNA (rRNA) gene is extremely a conserved gene amongst species of similar genus and within a species and can be employed as the novel benchmark for specifying bacteria [2]. The 16S rRNA gene sequences are very useful in studying bacterial phylogeny and nomenclature. With the existence of $16 \mathrm{~S}$ gene in virtually all bacteria, which exist as a multigene family the $16 \mathrm{~S}$ rRNA gene function for some time has never been altered, which suggest that indiscriminate sequence variations are more precise measures of time and 16S rRNA gene (1500 base pair) is big and good for informatics [3]. With the use of 16S rRNA sequence, several bacterial classes and even species have been renamed and reclassified; uncultivable bacteria grouping were possible through sequencing. Also phylogenetic relations have been determined, and the detection and classifications of new bacterial species by molecular characterization [4]. This technique has been fruitful in classifying Enterobacteriaceae species from a recipient of bone marrow transplant [4].

Several molecular subtyping techniques have been advanced to enhance the epidemiology of E. coli O157: H7 outbreaks understanding [5]. It is of importance to identify $E$. coli, and shiga toxin producing E. coli using molecular methods as culture based method may not properly identify this pathogen. Most media only identify bacteria to genus level and not species level. Proper identification is required so as to understand the type of measures to control this pathogen in food chain. However, the continuous advancement in molecular biology has resulted in advance of different molecular technique that can be used to identify and characterize bacteria including E. coli 0157 : $\mathrm{H}$ to specie levels [6]. Molecular subtyping, also known as fingerprinting of bacteria makes it promising to generate molecular profile of any bacteria [7]. Among the commonly use molecular tools are pulsed-field gel electrophoresis (PFGE), amplified fragment length polymorphism (AFLP), bacteriophage typing and Enterobacterial repetitive intergenic consensus-polymerase chain reaction (ERICPCR). This is a molecular subtyping method that is based on the use of PCR for analysis of the repetitive chromosomal sequences, called the Enterobacterial repetitive intergenic consensus (ERIC) [10]. It is said to be mostly utilized for clonal classification of diverse species of Enterobacteriaceae [8,9] and microbial diversity [10]. This molecular method generates genomic finger print that can different between bacterial strains [11]. According to [10], this molecular method or technique is fast, less laborious, simple and only require small amount of genomic DNA and set up equipment. ERIC-PCR is carried out using ERIC primers and amplified using PCR. Amplified PCR product will then be resolved using gel agarose electrophoresis. Obtained gel picture will then be analyzed using software before cluster analysis is performed and dendrogram constructed [10]. Random Amplified Polymorphic DNAPCR (RAPD-PCR) is a molecular typing tool that requires minimal DNA template [12]. This technique involves the use of primers of arbitrary sequences to randomly amplify template DNA using PCR [12].

RAPD-DNA is been utilized for strain-typing of bacteria [13, 14]. In 2001, Radu et al [15] used this method for the DNA fingerprinting of 28 strains of $E$. coli $\mathrm{O} 157$ : $\mathrm{H} 7$ isolated from haunch beef and three chicken meat burger samples correspondingly. Similarly, Sahilah [16] used this molecular method for genetic diversity and epidemiological study of the relationships of E. coli O157: $\mathrm{H} 7$ isolated from eggs and imported beef meat.

Shiga toxin-producing strains of E. coli O157: $\mathrm{H} 7$ are clonal in origin and they are phenotypically and genotypically closely alike [17]. In a recent review by, Etcheverria and Padola, [18] it was stated that the major virulence factor of $E$. coli O157: $\mathrm{H} 7$ is Shiga toxins encoded by $s t x 1$ and $s t x 2$ genes which can be produced singly or in combination. These toxins belongs to the AB5 protein toxins family containing enzymatically active A subunit, and $5 \mathrm{~B}$ subunits that are accountable for binding to the glycolipid globotriaosylceramide Gb3 which is the cellular receptor existing in organs of the body such as kidney, brain, liver, and pancreas [18]. The two main forms of Shiga toxins (stx 1 and $s t x 2$ ) are further characterized as stx $1 a$, stx $1 c$ and stx $1 d$, and highly heterogeneous stx2 with stx2a, stx2b, stx2c, stx 2 dact, stx $2 e$, stx $2 f$ and $s t x 2 g$ subtypes $[19,20]$. However, result from molecular epidemiological investigation shows that stx 2 , not stx 1 shiga toxins produced by this pathogen are responsible for the haemolytic uremic syndrome (HUS) [21].

Radu [22] revealed 12 strains of E. coli O157: $\mathrm{H} 7$ in 9 out of the 25 beef meat samples obtained from wholesale and retailing shops in Malaysia. However, it is necessary constantly monitor beef meat imported into Malaysia through the use of different molecular approach. Consequently, our study is to genetically characterized Shiga toxin-producing Escherichia coli strains isolated from imported beef meat in Malaysia using polymerase chain reaction (PCR) base analysis.

\section{Material and Methods}

\subsection{Meat Sample Collection}

Imported frozen beef meat samples totaling 74 were tested which came from two nations, including Australia (32 samples) and India (42 samples). The meat samples were bought from five different superstores in diverse places that include Tesco (Kajang), Carrefour (Mid-valley, Kuala Lumpur), Carrefour (Alamanda, Putrajaya), Jusco (Balakong) and Giant (Seri Kembangan) which are located in Selangor, Malaysia which begin from 2012 (April) to 2013 (October) weekly. The entire beef samples were raw, packed typically 4 to 6 samples were bought and kept at $20^{\circ} \mathrm{C}$ before usage and the testing was done within one week. Table 3 showed the distribution of sample sources and purchase location. 


\subsection{Isolation of E. coli and Shiga Toxin Producing E. coli from Frozen Beef Meat Imported}

The isolation of E. coli and shiga toxin producing E. coli was done following the method described by Charimba et al. [23]. $25 \mathrm{~g}$ of beef samples were improved into $225 \mathrm{ml}$ of Maximum Recovery Dilution (MRD). Samples were positioned in sterilized stomacher bags (Nasco Whirl-Pak ${ }^{\mathrm{TM}}$ ) and regimented at $300 \mathrm{rpm}$ for $90 \mathrm{~s}$ through the use of Lab Blender 400 (Interscience, France). Samples to be analyzed were diluted successively $\left(10^{-1}\right.$ to $\left.10^{-3}\right)$. Flurocult medium specific for $E$. coli was prepared and autoclaved then poured into petri dishes and allow for solidification. One mile of the three dissimilar dilutions for every sample was spread through the use of sterile glass spreader which submerged into a bottle of alcohol and passed it through the Bunsen burner swiftly so that the residue of alcohol will be burn. Samples to be analyzed were makes in triple and kept for 1824 hours at $37^{\circ} \mathrm{C}$. Sample with having positive colonies on the discriminatory medium (selective medium) revealed purple shine coloration, shown as probable of E. coli and later confirmed additionally through most probable number (MPN), standard biochemical tests and API20E kit to ratify the strains and were later utilized for PCR subsequently.

\subsection{Molecular Identification and Dna Extraction}

Extraction of E. coli DNA was carried out using the method of Jothikumar and Griffiths [24] with minor adjustment. E. coli colony isolated through selective agar from isolation part was enriched by suspending a loopful of colony in $20 \mathrm{ml}$ nutrient broth before $E$. coli DNA extraction was carry out,. The nutrient broth was later incubated over the night $\left( \pm 24\right.$ hours) at $37^{\circ} \mathrm{C}$. After the over the night incubations, $1.5 \mathrm{ml}$ of solution that consist of bacteria $(E$. coli) were transfer into $1.5 \mathrm{ml}$ micro-centrifuge tubes and the tubes were centrifuged using Minispin (Eppendorf, German) at 10000 r.p.m. for 10 mins. The supernatant was removed; this is done to get clear off the bacteria pellets which could remain in the micro-centrifuge tubes. $1.5 \mathrm{ml}$ of the broth solution were transfer once more to $2 \mathrm{ml}$ micro-centrifuge tubes through pipetting which consists of bacterial pellets and the tube was spin at $10000 \mathrm{rpm}$, for $10 \mathrm{mins}$ through the use of Minispin (Eppendorf, German). The bacteria pellets were later utilized for DNA extraction.

The DNA extraction was achieved through addition of $1 \mathrm{ml}$ of sterilized purified water into the micro-centrifuge tubes which consists of the pellets of the bacteria. The tube containing the bacteria pellets was later vortexed for about $10 \mathrm{~s}$ for proper mixture of the bacterial pellets with purified water and it was subsequently wrapped using parafilm sheet. After that, the tubes containing the samples were floats using water bath for $10 \mathrm{mins}$ at $98^{\circ} \mathrm{C}$. After 10 mins the tube was immediately transferred into the freezer of $-20^{\circ} \mathrm{C}$ for 10 mins. All of these steps were repeated again and the tubes finally were centrifuged at 10000 rpm, for 5 mins by the use of Minispin (Eppendorf, German) so that debris from the sample can be removed. The supernatant was move to a fresh sterilized $1.5 \mathrm{ml}$ micro-centrifuge tubes and the DNA concentration was measured through Maestronano Spectrophotometer (Maestrogen, USA). The entire DNA extracted was kept in $-20^{\circ} \mathrm{C}$ until use for subsequent test using PCR $[25,26]$.

\subsection{Plasmid Profiling}

\subsubsection{Plasmid Extraction}

Plasmid isolation was done through the use of the PureYield ${ }^{\text {TM }}$ Plasmid Miniprep System kit (Promega, USA) to get the high-quality plasmid DNA following manufacturer's instruction while $600 \mu \mathrm{l}$ of culture bacteria was full-grown in Luria-Bertani (LB) medium was put into a $1.5 \mathrm{ml}$ micro-centrifuge tubes. Addition and mixing through inverting the tubes about six times in one hundred microliter of cell lysis buffer was done. After the solution change to clear blue from cloudy, it indicates whole lysis. The next step was preceded in 2 min time. Excess lysis could leads in denaturing the plasmid DNA. The subsequent sets of ten samples were continued after the first set is completely neutralized and exhaustively mixed $[27,28]$. Next, is the addition of $350 \mu \mathrm{l}$ of cold $\left(4-8^{\circ} \mathrm{C}\right)$ neutralization solution and mixed exhaustively through inverting tubes. The samples change to yellow after neutralization was completed which result to formation of yellow precipitate. The samples were inverted three more time to guarantee whole neutralization. Then samples were centrifuged at high speed for $3 \mathrm{~min}$. After that, the supernatant $(\sim 900 \mu \mathrm{l})$ was put into a PureYield ${ }^{\mathrm{TM}}$ Minicolumn and the cell debris pellets were not upset. For maximum yield, the supernatant was transferred with a pipette. The mini column is later place to a PureYield ${ }^{\mathrm{TM}}$ collection tubes, and centrifuged at high revolution for $15 \mathrm{sec}$. The flow through was thrown away, while the mini column was replace back into the same PureYield ${ }^{\mathrm{TM}}$ collection tubes. Addition of $200 \mu \mathrm{l}$ of Endotoxin Removal Wash to the mini column was done and centrifuged at high revolution for 15 sec. It's not essential to empty the PureYield ${ }^{\mathrm{TM}}$ collection tubes. Then, $400 \mu \mathrm{l}$ of column wash solution was added to the mini column and centrifuged at high revolution for $30 \mathrm{sec}$. Next, the mini column was relocated to a clean $1.5 \mathrm{ml}$ microcentrifuge tubes, addition of $30 \mu \mathrm{l}$ of Elution Buffer right to the mini column matrix was done. The micro centrifuge tube was incubated at room temperature for $1 \mathrm{~min}$ and centrifuged at high revolution for $15 \mathrm{sec}$ for elution of the plasmid DNA. The micro centrifuge tube cap was closed and eluted plasmid DNA was kept at $-20^{\circ} \mathrm{C}$ until use for analysis.

\subsubsection{Plasmid DNA Analysis}

After the plasmid DNA isolated, gel electrophoresis was done in accordance to the technique defined previously from section $3.3 .3($ b) to analyse the DNA pattern on $1 \%(\mathrm{w} / \mathrm{v})$ agarose gel. The gel electrophoresis was run at $85 \mathrm{~V}$ for 1 hour and Lambda DNA-HindIII Digest DNA ladder (New England BioLabs, USA) was utilized as DNA marker. Then the gels were view using UV light and documented by gel documentation of GeneSys G: BOX EF2 (Syngene, USA) and gel image was recorded and the plasmid DNA bands produced were analysed $[28,29]$. 


\subsection{Sub-typing of Shiga Toxin Producing E. coli}

\subsubsection{Enterobacterial Repetitive Intergenic}

Consensus-Polymerase Chain Reaction (ERIC-PCR)

In this section, we used one pair of Enterobacterial Repetitive Intergenic Consensus (ERIC) primer, as reported by Sahilah et al [16]: ERIC-1 (5'-CAC TTA GGG GTC CTC GAA TGT A -3') and ERIC-2 (5'-AAG TAA GTG ACT GGG GTG AGC G -3'). The PCR assay using ERIC primer was done in a concluding volume of $50 \mu$ containing $25 \mu \mathrm{l}$ of 2X DreamTaq Green PCR Master Mix (Thermo Scientific, USA), $1 \mu \mathrm{l}$ of $100 \mu \mathrm{M}$ of each of the forward and reverse primers, $1 \mu \mathrm{l}$ of about $100 \mathrm{ng}$ DNA templates and nuclease free water marking-up to the volume. Negative controls and positive DNA sample were included in every reaction through addition of $1 \mu \mathrm{l}$ of roughly $100 \mathrm{ng}$ E. coli O157: H7 DNA templates and $10 \mu \mathrm{l}$ of water (nuclease free) in PCR assay.

Amplification of PCR was done in the $\mathrm{MyCycler}^{\mathrm{TM}}$ Thermal Cycler (Bio-Rad, USA) with a temperature programme containing of primary denaturation for $1 \mathrm{~min}$ at $95^{\circ} \mathrm{C}$ which was follow by 35 cycles of denaturation's for 45 $\mathrm{s}$ at $92^{\circ} \mathrm{C}$, annealing for at $52^{\circ} \mathrm{C}$ for a min and polymerization for 20 mins at $70^{\circ} \mathrm{C}$. The concluding elongation was at $70^{\circ} \mathrm{C}$ for 20 mins. After complete running of the PCR, in the master cycler, the PCR products obtained was electrophoresed through $1.5 \%$ agarose gel $(\mathrm{w} / \mathrm{v})$ to observe the pattern of DNA band produced on gel surface. The amplicons were analyzed by gel electrophoresis using $1 \%$ (w/v) agarose gel in 1X TAE buffer $(40 \mathrm{mM}$ Tris-OH, 20 $\mathrm{mM}$ acetic acid and $1 \mathrm{mM}$ of EDTA, $\mathrm{pH} 7.6$ ) at $90 \mathrm{~V}$ for 45 mins and pre stained by MaestroSafe ${ }^{\mathrm{TM}}$ Nucleic Acid Prestained (Maestrogen, USA). A $1 \mathrm{~kb}$ DNA ladder (Fermentas, Lithuania) was used as DNA size reference. The gels were view under UV light through gel documentation of GeneSys G: BOX EF ${ }^{2}$ (Syngene, USA) and gel image was taken and documented concurrently. The DNA band pattern produced on gel image were captured and recorded then analyzed through dendogram software to get the final results of cluster and single band for this test.

\subsubsection{Random Amplified Polymorphic DNA-PCR (RAPD-PCR)}

There are seven types of primers used in this section of Random Amplified Polymorphic DNA-PCR (RAPD-PCR) namely Gen8, Gen9, A1, A7, A10, OPAR8 and OPAR20. All of these primers were reported by several different authors and all the primer sequences are in Table 1. The PCR assay for this section was done in $50 \mu \mathrm{l}$ of total volume consisting of $25 \mu 1$ of 2X DreamTaq Green PCR Master Mix (Thermo Scientific, USA), $1 \mu \mathrm{l}$ of $100 \mu \mathrm{M}$ each of the forward and reverse primers, $1 \mu \mathrm{l}$ of approximately $100 \mathrm{ng}$ DNA template and nuclease free water markin-up to the volume. A positive and negative control was included together each time when the PCR was carried out for different types of primers.

Temperature cycle of PCR amplification was set by the use MyCycler $^{\mathrm{TM}}$ Thermal Cycler (Bio-Rad, USA) that carried out separately for each different type of primers. Table 2 showed temperature cycle of different primers used. Usually the PCR temperature cycle involved temperature of denaturation, annealing and extension or elongation. After finished PCR amplification, the amplified DNA was observed through $1 \%$ (primers of A1, A7 and A10) and 1.5\% (primers of Gen8, Gen9, OPAR8 and OPAR20) of agarose gel at $100 \mathrm{~V}$ for 45 mins. The DNA band pattern produced on gel image were then analyzed through dendogram unweight average linkage analysis (UPGMA) software to get the final results.

Table 1. List of primer sequences used in RAPD-PCR analysis.

\begin{tabular}{lll}
\hline Primer Name & Sequences (5'-3') & Reference \\
\hline Gen8 & 5'-GGA AGA CAA C -3' & Sahilah et al. (2010) \\
Gen9 & 5'-AGA AGC GAT G -3' \\
A1 & 5'-TGC GGC TTA C -3' \\
A7 & 5'-TCA CGG TGC A -3', \\
A10 & 5'-GTA GAC GAG C -3' & Hurtado and Rodríguez-Valera (1999) \\
OPAR8 & 5'-TGG GGC TGT C -3' \\
OPAR20 & 5'-ACG GCA AGG A -3' & Nor'aishah (2008) \\
\hline
\end{tabular}

Table 2. Temperature cycle for RAPD-PCR amplification.

\begin{tabular}{ll}
\hline Primer Name & PCR cycle \\
\hline Gen8 & Initial denaturation at $94^{\circ} \mathrm{C}$ for $5 \mathrm{~min}$, followed by 45 cycles of denaturation at $94^{\circ} \mathrm{C}$ for 1 min, annealing at $35^{\circ} \mathrm{C}$ for 1 min and \\
Gen9 & polymerization at $72^{\circ} \mathrm{C}$ for $2 \mathrm{~min}$. Final elongation was at $72^{\circ} \mathrm{C}$ for 7 min. \\
A1 & 35 cycles of: denaturation at $94^{\circ} \mathrm{C}$ for $30 \mathrm{~s}$, annealing at $36^{\circ} \mathrm{C}$ for $1 \mathrm{~min}$, and extension at $72^{\circ} \mathrm{C}$ for 2 min. A final extension was \\
A7 & performed at $72^{\circ} \mathrm{C}$ for $10 \mathrm{~min}$. \\
A10 & Initial denaturation at $94^{\circ} \mathrm{C}$ for 5 min followed by 45 cycles of denaturation at $94^{\circ} \mathrm{C}$ for 1 min, annealing at $35^{\circ} \mathrm{C}$ for 1 min and \\
OPAR8 & polymerization at $72^{\circ} \mathrm{C}$ for 2 min. Final elongation was at $72^{\circ} \mathrm{C}$ for 7 min. \\
OPAR20 &
\end{tabular}

\section{Result}

\subsection{Plasmid Profiling}

Plasmid profiling showed 16 patterns based on size and 4 patterns on gel (Table 3 Figures 1 and 2). Using both the phenotypical and genotypical approaches revealed a wide heterogeneity among imported beef isolates of E. coli. The plasmid profiles of the isolates are listed in Table 3.

In this study, isolated plasmids from shiga toxin producing E. coli varied in sizes. The sizes are from 4.3 -23.1 kilo base 
(kb) Table 3. All the isolates harbored plasmid except only one strain. Sixty two (62) isolates were found to harbor plasmid with size $23.2 \mathrm{~kb}$ while 43 isolates harbored more than a single plasmid.

Table 3. Plasmid profiles analysis of shiga toxin producing E. coli.

\begin{tabular}{|c|c|c|c|c|}
\hline \multirow{3}{*}{$\begin{array}{l}\text { Strain No. } \\
1\end{array}$} & \multirow{3}{*}{$\begin{array}{l}\text { Locations } \\
\text { Carrefour Alamanda-Indian Buffalo Block frozen }\end{array}$} & \multicolumn{3}{|c|}{ Plasmid profiles } \\
\hline & & \multicolumn{3}{|c|}{ Plasmid sizes $(\mathrm{Kb})$ (patterns) } \\
\hline & & (A) & 23.1 & (P1) \\
\hline 2 & Tesco Kajang -Indian Buffalo Tlon FZ & (A) & 23.1 & (P1) \\
\hline 3 & Tesco Kajang -Indian Buffalo Tlon FZ & (A) & 23.1 & (P1) \\
\hline 4 & Tesco Kajang -Indian Buffalo Tlon FZ & (A) & $23.1,23.2$ & $(\mathrm{P} 2)$ \\
\hline 5 & Tesco Kajang -Indian Buffalo Tlon FZ & (A) & 23.1 & (P1) \\
\hline 6 & Tesco Kajang -Indian Buffalo Tlon FZ & (A) & 23.1 & (P1) \\
\hline 7 & Tesco Kajang -Indian Buffalo Tlon FZ & (A) & $23.1,23.2$ & $(\mathrm{P} 2)$ \\
\hline 8 & Tesco Kajang -Indian Buffalo Tlon FZ & (A) & 23.1 & (P1) \\
\hline 9 & Tesco Kajang -Indian Buffalo Tlon FZ & (A) & 23.1 & (P1) \\
\hline 10 & Tesco Kajang -Indian Buffalo Tlon FZ & (A) & $23.1,20$ & (P3) \\
\hline 11 & Tesco Kajang -Indian Buffalo Tlon FZ & (A) & 23.1 & (P1) \\
\hline 12 & Tesco Kajang -Indian Buffalo Tlon FZ & (A) & 23.1 & (P1) \\
\hline 13 & Tesco Kajang -Indian Buffalo Tlon FZ & A2 & 23.1 & P1 \\
\hline 14 & Tesco Kajang -Indian Buffalo Tlon FZ & $\mathrm{A} 2$ & 23.1 & $\mathrm{P} 1$ \\
\hline 15 & Tesco Kajang -Indian Buffalo Tlon FZ & A2 & 23.1 & $\mathrm{P} 1$ \\
\hline 16 & Tesco Kajang -Indian Buffalo Tlon FZ & A2 & 23.1 & $\mathrm{P} 1$ \\
\hline 17 & Tesco Kajang - India Buffalo CTEN FZ & A4 & 23.1 & $\mathrm{P} 1$ \\
\hline 18 & Tesco Kajang - India Buffalo CTEN FZ & A3 & $23.1,9.4$ & $\mathrm{P} 4$ \\
\hline 19 & India Buffalo CTEN FZ & A2 & $23.1,9.4$ & P4 \\
\hline 20 & Carrefour Mid Valley-Indian topside & A5 & 23.1 & $\mathrm{P} 1$ \\
\hline 21 & Carrefour Mid Valley-Indian topside & $\mathrm{A} 2$ & 23.1 & $\mathrm{P} 1$ \\
\hline 22 & Tesco Kajang -Indian Cube FRZ & A2 & 23.1 & $\mathrm{P} 1$ \\
\hline 23 & Carrefour Alamanda-Indian topside & $\mathrm{A} 2$ & 23.1 & $\mathrm{P} 1$ \\
\hline 24 & Jusco Balakong-India buffalo FQ site L & A6 & 23.1 & $\mathrm{P} 1$ \\
\hline 25 & Giant Seri Kembangan-Indian buffalo block & A6 & $23.1,4.3$ & P5 \\
\hline 26 & Giant Seri Kembangan-Indian buffalo & A7 & $23.1,23.2$ & $\mathrm{P} 2$ \\
\hline 27 & Giant Seri Kembangan-Indian buffalo block & $\mathrm{A} 2$ & $23.1,23.2$ & $\mathrm{P} 2$ \\
\hline 28 & Giant Seri Kembangan-Indian buffalo block & A6 & $23.1,23.2$ & $\mathrm{P} 2$ \\
\hline 29 & Giant Seri Kembangan-Indian buffalo block & A8 & $23.1,23.2,6.5$ & P7 \\
\hline 30 & Giant Seri Kembangan-Indian buffalo & A7 & $23.1,23.2$ & $\mathrm{P} 2$ \\
\hline 31 & Giant Seri Kembangan-Indian buffalo block & A3 & $23.1,23.2$ & $\mathrm{P} 2$ \\
\hline 32 & Giant Seri Kembangan-Indian buffalo block & A8 & 23.1 & $\mathrm{P} 1$ \\
\hline 33 & Giant Seri Kembangan-Indian buffalo block & A8 & 23.1 & $\mathrm{P} 1$ \\
\hline 34 & Giant Seri Kembangan-Indian buffalo & A8 & $23.1,23.2,20$ & P6 \\
\hline 35 & Giant Seri Kembangan-Indian buffalo block & A2 & $23.1,23.2$ & $\mathrm{P} 2$ \\
\hline 36 & Giant Seri Kembangan-Indian buffalo block & $\mathrm{A} 2$ & 23.1 & $\mathrm{P} 1$ \\
\hline 37 & Giant Seri Kembangan-Indian buffalo block & $\mathrm{A} 2$ & 23.1 & $\mathrm{P} 1$ \\
\hline 38 & Giant Seri Kembangan-Indian buffalo block & A8 & 23.1 & $\mathrm{P} 1$ \\
\hline 39 & Giant Seri Kembangan-Indian buffalo block & A8 & 23.1 & $\mathrm{P} 1$ \\
\hline 40 & Giant Seri Kembangan-Indian buffalo block & A9 & 23.1 & $\mathrm{P} 1$ \\
\hline 41 & Giant Seri Kembangan-Indian buffalo block & A2 & $23.1,4.3$ & P5 \\
\hline 42 & Giant Seri Kembangan-Indian buffalo block & A8 & 23.1 & $\mathrm{P} 1$ \\
\hline 43 & Carrefour Alamanda-AUST. TOPSIDE ST & A10 & $23.1,20,4.3$ & P8 \\
\hline 44 & Carrefour Alamanda-AUST. TOPSIDE ST & A8 & $23.1,23.2,20,6.5$ & P9 \\
\hline 45 & Carrefour Mid Valley-AUST. Aris Tips & A 10 & $23.1,23.2,6.5,4.3$ & $\mathrm{P} 10$ \\
\hline 46 & Carrefour Mid Valley-AUST. Rumpsteak & A8 & 23.1 & $\mathrm{P} 1$ \\
\hline 47 & Carrefour Mid Valley-AUST. KNUCKEL BL & A8 & $23.1,23.2,20$ & P6 \\
\hline 48 & Carrefour Mid Valley- AUST. outside BL & A8 & $23.1,23.2$ & $\mathrm{P} 2$ \\
\hline 49 & Carrefour Mid Valley-AUST. TOPSIDE BL & A8 & 23.1 & $\mathrm{P} 1$ \\
\hline 50 & Tesco Kajang-AUST. Daging pejal & A8 & $23.1,23.2,4.3$ & P11 \\
\hline 51 & Carrefour Mid Valley-AUST. Tender steak & A8 & $23.1,9.4$ & P4 \\
\hline 52 & Carrefour Mid Valley-AUST. Round steak & A8 & $23.1,23.2,6.5$ & P7 \\
\hline 53 & Carrefour Mid Valley-AUST. For BBQ & A8 & $23.1,20,4.3$ & P8 \\
\hline 54 & Carrefour Alamanda-AUST. Topside ST & $\mathrm{A} 2$ & $23.1,23.2,20$ & P6 \\
\hline 55 & Carrefour Mid Valley-AUST. SOUPM & A11 & $23 \cdot 1,23 \cdot 2,20,9.4$ & $\mathrm{P} 12$ \\
\hline 56 & Carrefour Mid Valley- AUST. Iris tipis & A8 & 23.1 & P1 \\
\hline 57 & Carrefour Alamanda-AUST. Topside ST & A8 & 23.1 & $\mathrm{P} 1$ \\
\hline
\end{tabular}




\begin{tabular}{lllll}
\hline \multirow{2}{*}{ Strain No. } & \multirow{2}{*}{ Locations } & \multicolumn{2}{l}{ Plasmid profiles } \\
\cline { 3 - 4 } & & \multicolumn{2}{l}{ Plasmid sizes (Kb) (patterns) } \\
\hline 58 & Carrefour Mid Valley-AUST. Round steak & A2 & 23.1 & P1 \\
59 & Carrefour Mid Valley-AUST. Rumpsteak & A8 & $23.1,23.2,20,9.4,6.5$ & P13 \\
60 & Giant Seri Kembangan-AUST. Beef BL OCK & A8 & $23.1,23.2,20$ & P6 \\
61 & Giant Seri Kembangan-AUST. Beef CU BES & A8 & $23.1,20,4.3$ & P8 \\
62 & Jusco Mid Valley-AUST. CH Rump yak In IKU & A8 & 23.1 & P1 \\
63 & Jusco Balakong-AUST. Chilled topside steak & A3 & $23.1,20$ & P3 \\
64 & Jusco Balakong-AUST. Chilled topside steak & A8 & 23.1 & P1 \\
65 & Carrefour Alamanda-AUST. Prime eye round & A8 & $23.1,6.5,4.3$ & P14 \\
66 & Carrefour Alamanda-AUST. Topside ST & A3 & $23.1,6.5,4.3$ & \\
67 & Carrefour Alamanda-AUST. Topside ST & A3 & - & \\
68 & Carrefour Alamanda-AUST. Toside S & A12 & 4.3 & P15 \\
69 & Carrefour Mid Valley-AUST. Chuck Tend & A8 & $6.5,4.3$ & P16 \\
70 & Carrefour Alamanda-AUST. KNUCKEL BL & A8 & $23.1,23.2,20$ & P6 \\
\hline
\end{tabular}

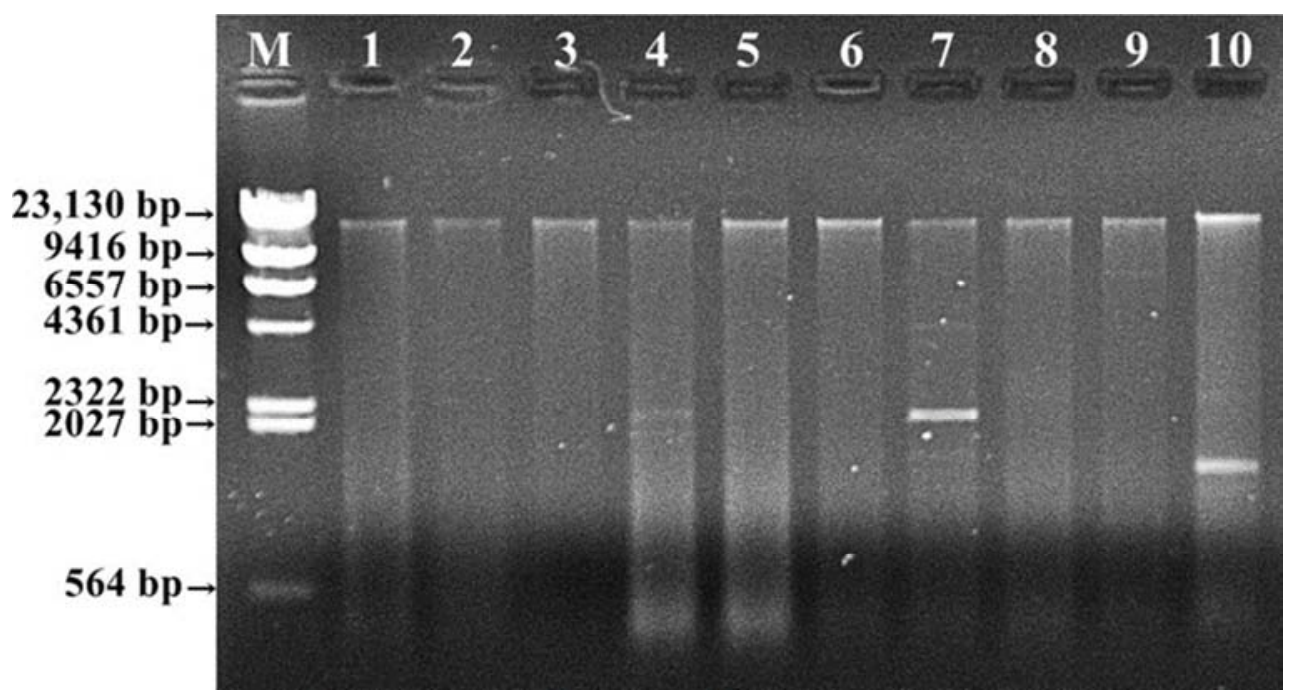

Figure 1. Plasmid identification using PureYield ${ }^{\mathrm{TM}}$ Plasmid Miniprep System kit (Promega, USA) on 1\% (w/v) agarose gel. Lane M: Lambda. DNA-HindIII Digest DNA ladder. Lane 1-10: EC.

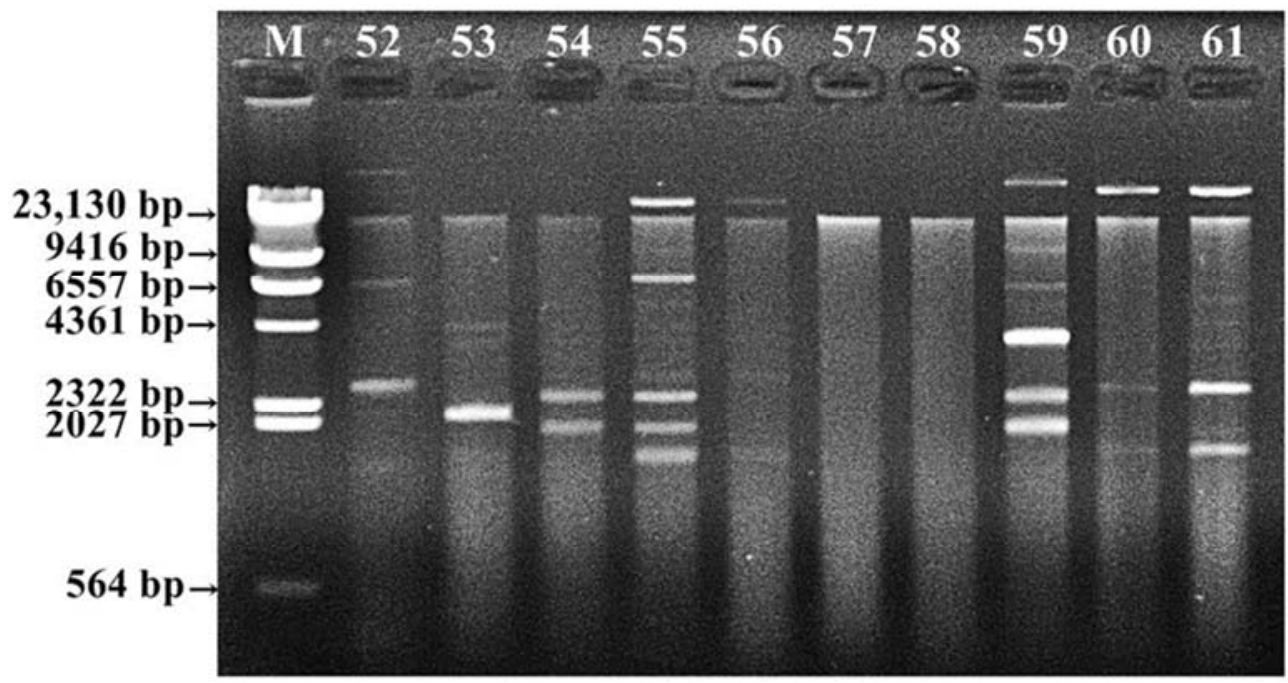

Figure 2. Plasmid identification using PureYield ${ }^{\mathrm{TM}}$ Plasmid Miniprep System kit (Promega, USA) on 1\% (w/v) agarose gel. Lane M: Lambda DNA-HindIII Digest DNA ladder. Lane 52-60: EC.

\subsection{Eric-pcr and Rapd-pcr Analysis}

The outcomes of the ERIC (Figures 3 and 4), RAPD-PCR (Figures 5 and 6) were analyzed using Gel Compare 11 software, the rest of the results shown in figure 7 to 13. ERIC-PCR with primers ERIC1R and ERIC2 discriminated the E. coli strains into 4 clusters and 2 single isolates at a similarity level of $80 \%$ figure 14. RAPD-PCR with primer Gene 8 distinguished the $E$. 
coli strains into 15 clusters and 8 single strains figure 15, RAPDPCR using primer Gene 9 distinguished the E.coli into 16 clusters and 8 single strains figure 16, while RAPD-PCR using primer Opar 8 differentiated the $E$. coli into 8 clusters and 3 single strains figure 17, RAPD-PCR using primer Opar 20 differentiated the E. coli into 7 clusters and 4 single strains figure 18, RAPD-PCR using primer A1 differentiated the $E$. coli into 3 clusters and 6 single strains figure 19, RAPD-PCR using primer A7 differentiated the $E$. coli into 12clusters and 6 single strains figure 20 and RAPD using primer A10 differentiated the $E$. coli into 8 clusters and 4 single strains figure 21 .

In this work, the use of molecular typing technique, ERICPCR, and RAPD-PCR methods were utilized to subtype $E$. coli isolated from imported frozen meat sold in Malaysia hyper and super markets. The analysis of data through the use of average linkage (UPGMA, unweight group pair technique with arithmetic averages) using Gel compare 11 software which was displayed in dendrograms, for the, ERIC-PCR and RAPD-PCR (RAPD Gen 8, Gen 9), (Opar 8 and Opar 20), (RAPD A1, RAPD A7and RAPD A10) analysis, produced various cluster as follows: ERIC-PCR produces 4 clusters and 2 single isolates and RAPD-PCR (RAPD Gen 8, Gen 9), produces 15 clusters and 8 single isolates, 16 clusters and 8 single isolates respectively figures 14 and 15. The PCR analysis using OPAR 8 and OPAR 20 produces 8 clusters and 3 single isolates and 7 clusters with 4 single isolates at a similar levels observed respectively while, RAPD A1, RAPD A7and RAPD A10 produces 3 clusters and 6 single isolates, 12 clusters and 6 single isolates and 8 clusters and 4 single isolates respectively figures 15

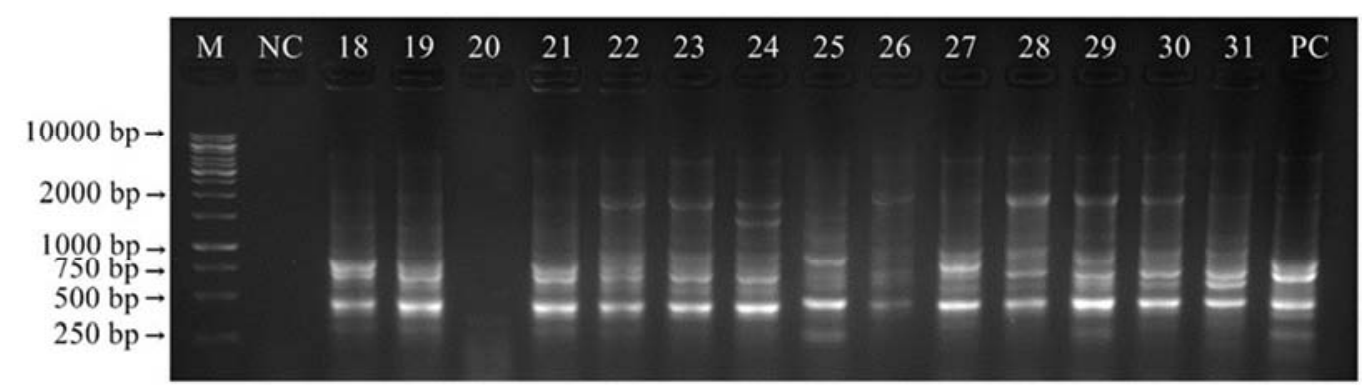

Figure 3. ERIC-PCR using ERIC 1and ERIC 2 primers on 1.5\% (w/v) agarose gel. Lane M: $1 \mathrm{~kb}$ ladder. Lane NC: negative control. Lane 18-31: EC. Lane PC: positive control.

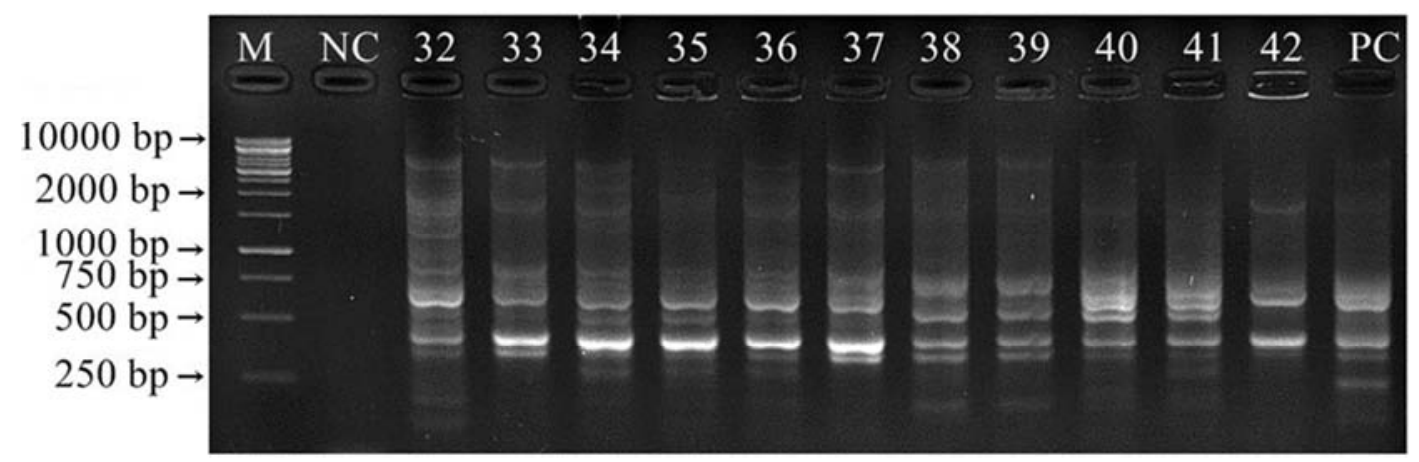

Figure 4. ERIC-PCR using ERIC 1and ERIC 2 primers on 1.5\% (w/v) agarose gel. Lane M: ladder. Lane NC: negative control. Lane 32-42: EC. Lane PC: positive control.

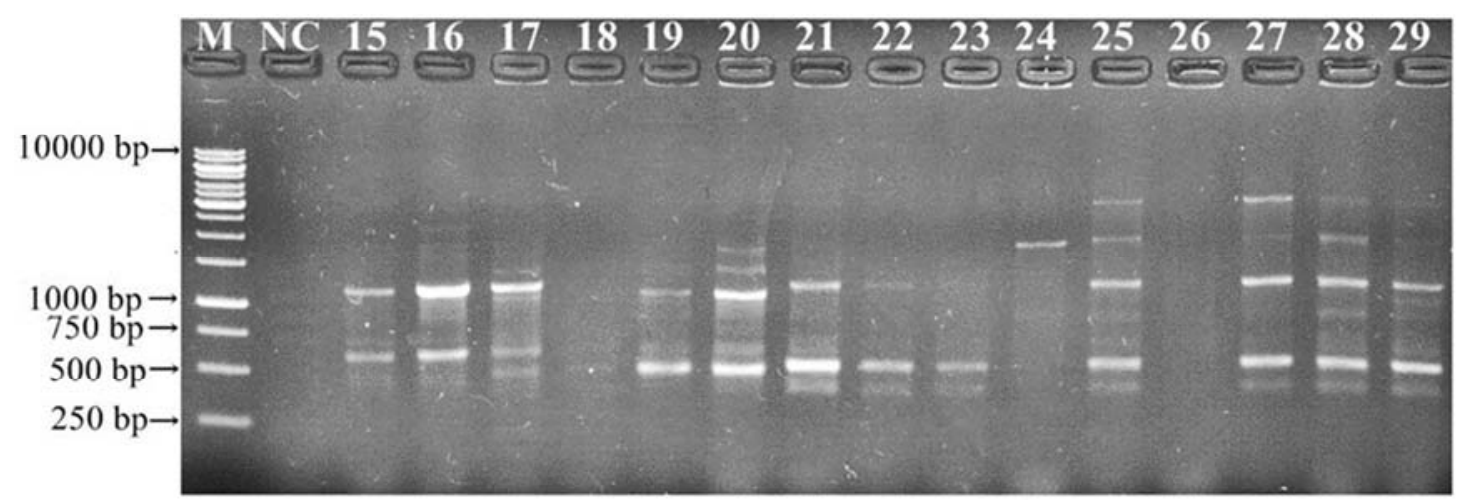

Figure 5. RAPD-PCR using GENE 8 primer on 1.5\% (w/v) agarose gel. M: $1 \mathrm{~kb}$ ladder. Lane NC: negative control. Lane 15-29: EC. 


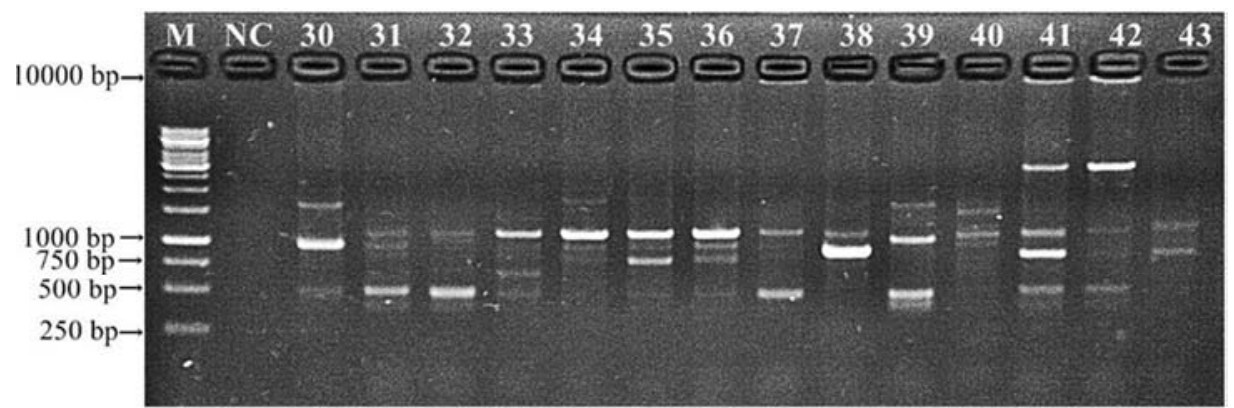

Figure 6. RAPD-PCR using GENE 8 primer on 1.5\% (w/v) agarose gel. Lane M: 1 kb ladder. Lane NC: negative control. Lane 30-43: EC.

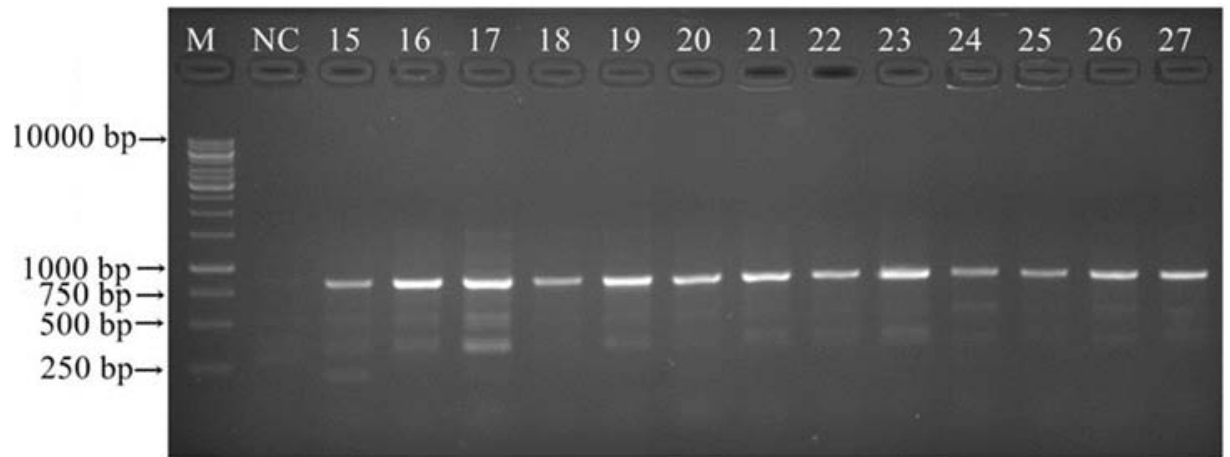

Figure 7. RAPD-PCR using GENE 9 primer on 1.5\% (w/v) agarose gel. Lane M: 1 kb ladder. Lane NC: negative control. Lane 15-27: EC.

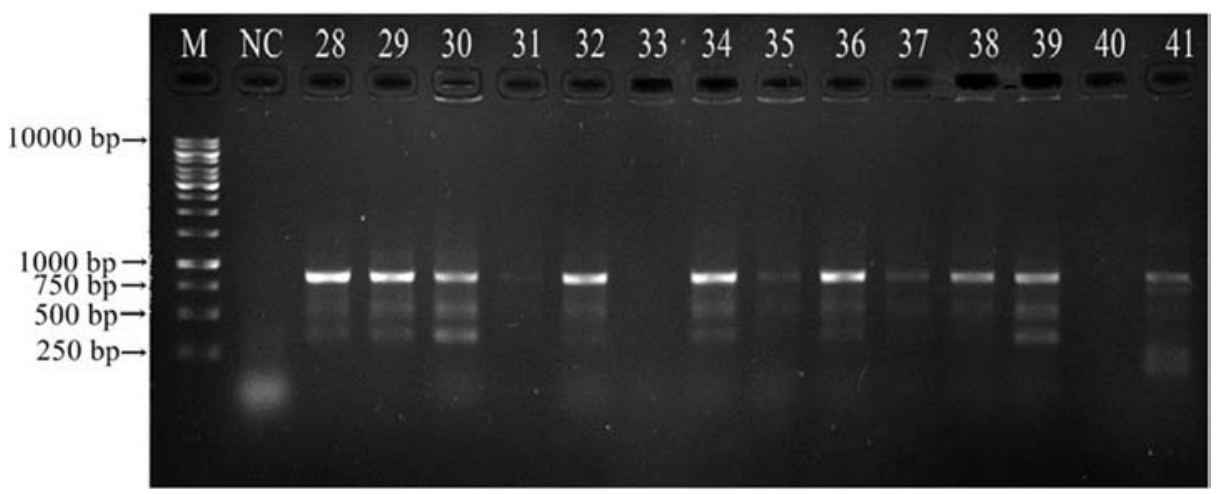

Figure 8. RAPD-PCR using GENE 9 primer on 1.5\% (w/v) agarose gel. Lane M: $1 \mathrm{~kb}$ ladder. Lane NC: negative control. Lane 28-41: EC.

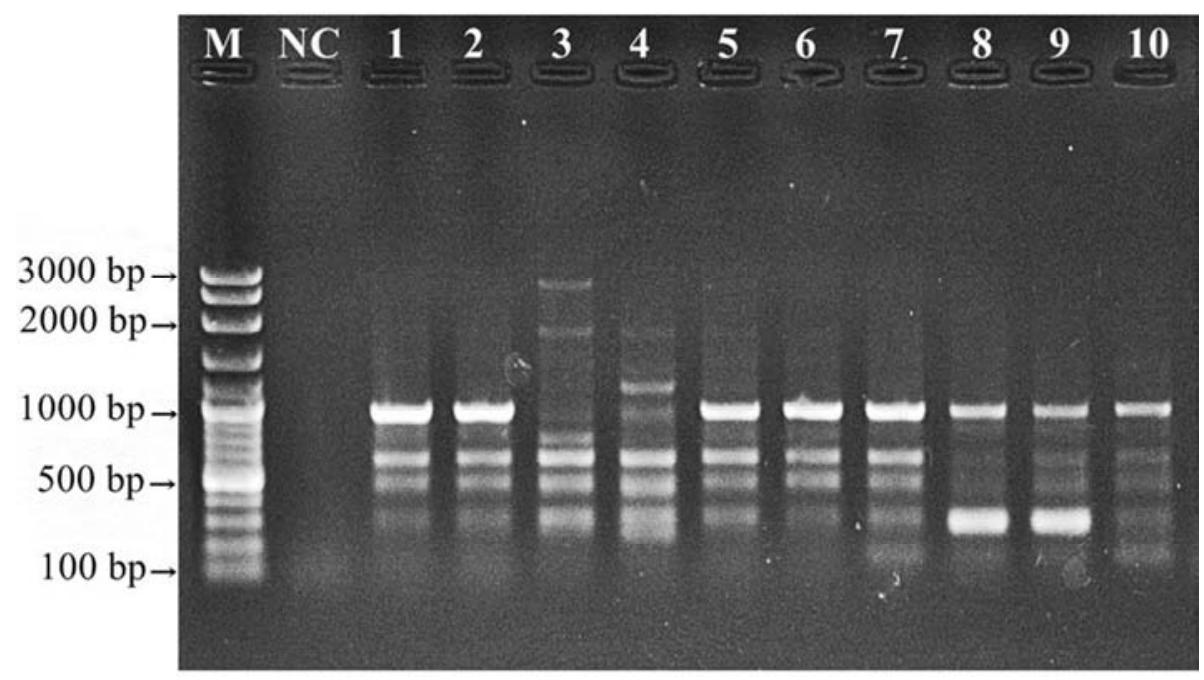

Figure 9. RAPD-PCR using OPAR 8 primer on 1.5\% (w/v) agarose gel. Lane M: 123 bp ladder. Lane NC: negative control. Lane 1-10: EC. 
60 Abuelhassan Nawal Noureldaim et al:: Genetic Characterization of Shiga Toxin-producing Escherichia coli Strains Isolated from Imported Beef Meat in Malaysia Using Polymerase Chain Reaction Analysis

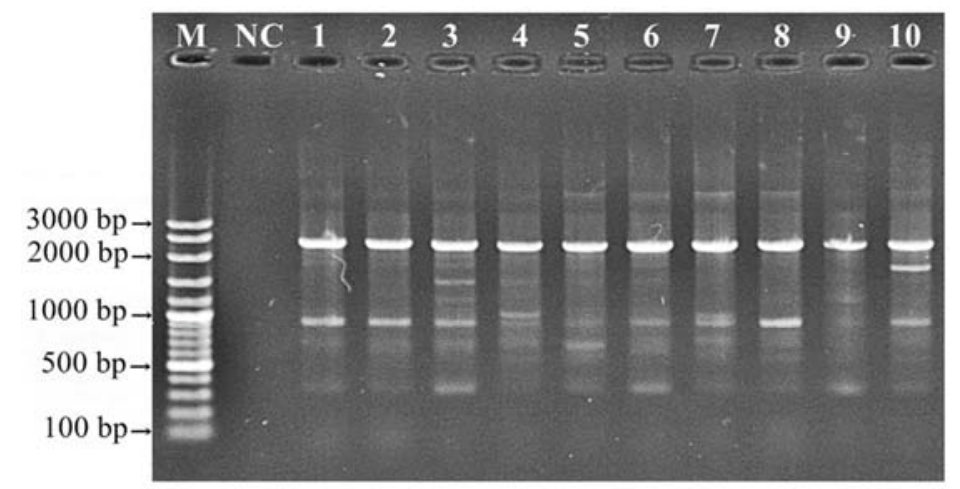

Figure 10. RAPD-PCR using OPAR 20 primer on 1.5\% (w/v) agarose gel. Lane M: 123 bp ladder. Lane NC: negative control. Lane 1-10: EC.

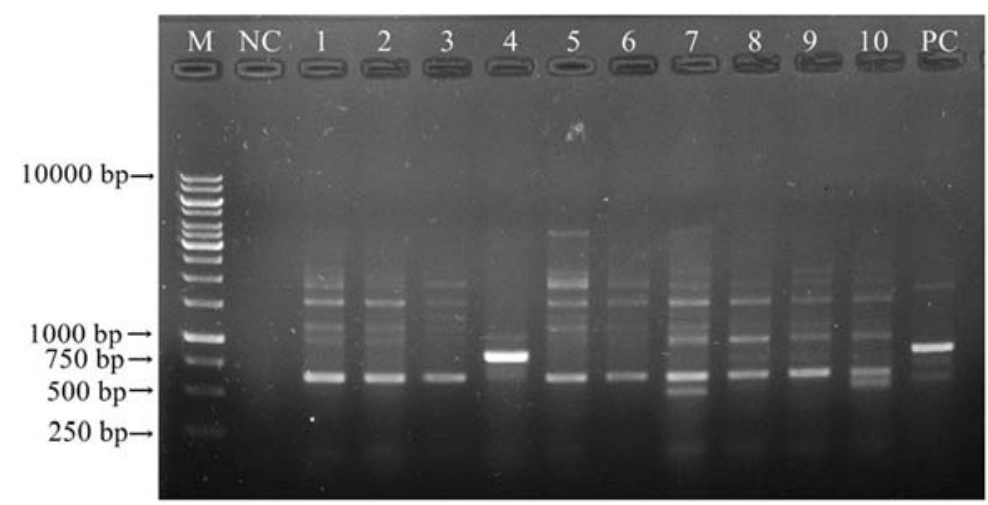

Figure 11. RAPD-PCR using A1 primer on 1.0\% (w/v) agarose gel. Lane M: $1 \mathrm{~kb}$ ladder. Lane NC: negative control. Lane 1-10: EC. Lane PC: positive control.

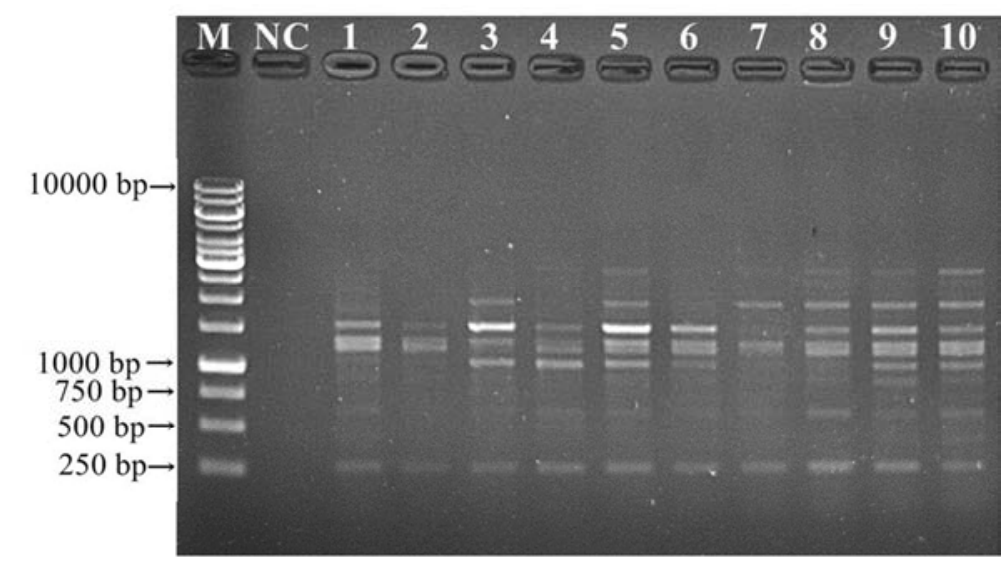

Figure 12. RAPD-PCR using A7 primer on 1.0\% (w/v) agarose gel. Lane M: $1 \mathrm{~kb}$ ladder. Lane NC: negative control. Lane 1-10: EC.

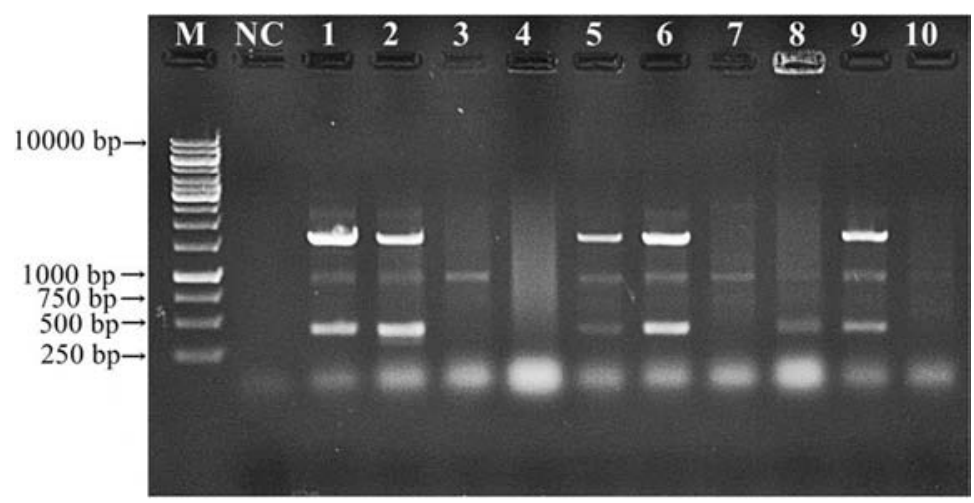

Figure 13. RAPD-PCR using A10 primer on 1.0\% (w/v) agarose gel. Lane M: 1 kb ladder. Lane NC: negative control. Lane 1-10. 
Pearson correlation $[0.0 \%-100.0 \%]$
ERIC

ERIC

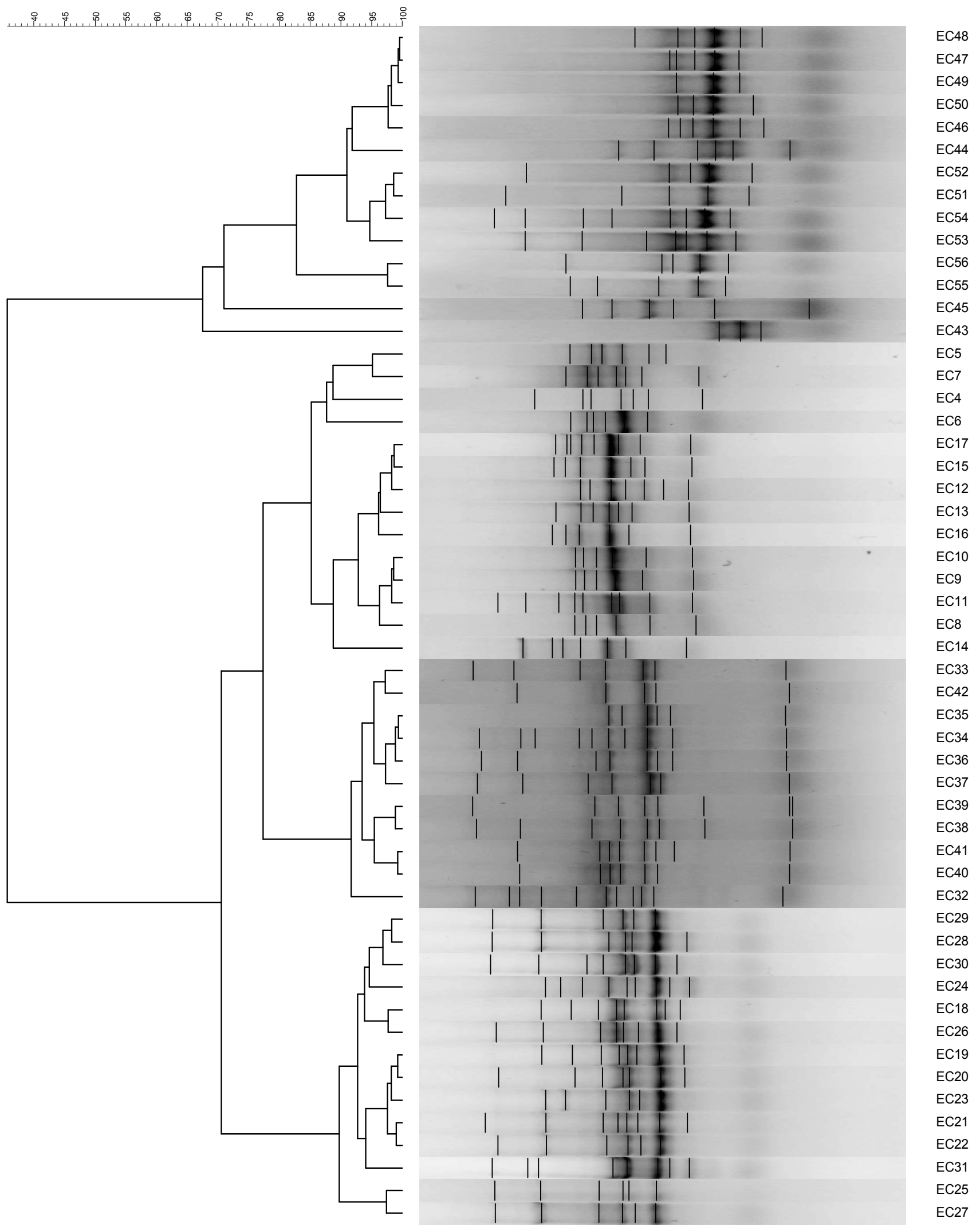

Figure 14. Dendogram of typeable E. coli isolates produced from ERIC analysis using average linkage unweighted group pair method with arithmetic average (UPGMA). 
62 Abuelhassan Nawal Noureldaim et al:: Genetic Characterization of Shiga Toxin-producing Escherichia coli Strains Isolated from Imported Beef Meat in Malaysia Using Polymerase Chain Reaction Analysis

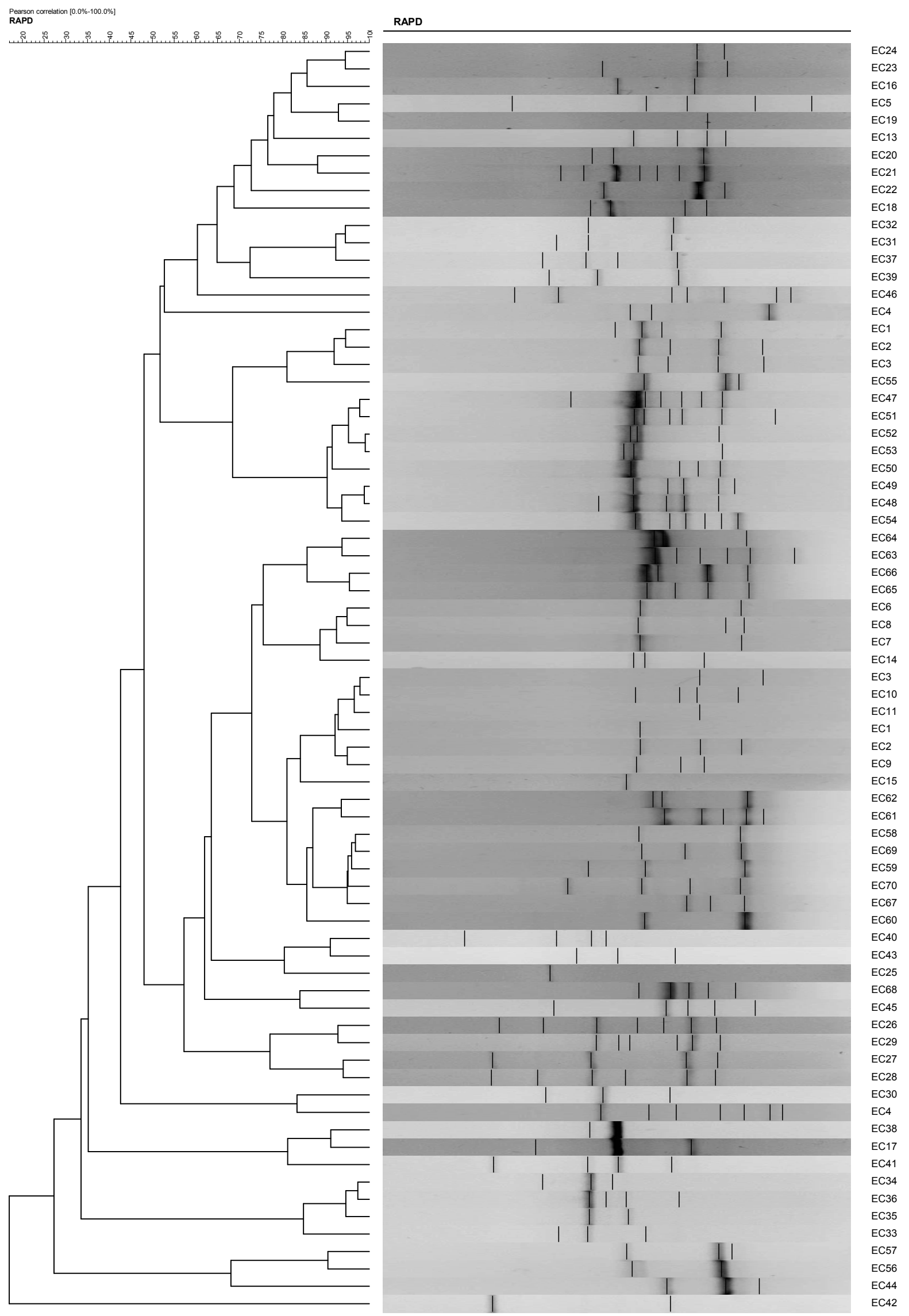

Figure 15. Dendogram of typable E. coli isolates from RAPD analysis (Gen 8) using average linkage unweighted group pair method with arithmetic average (UPGMA). 


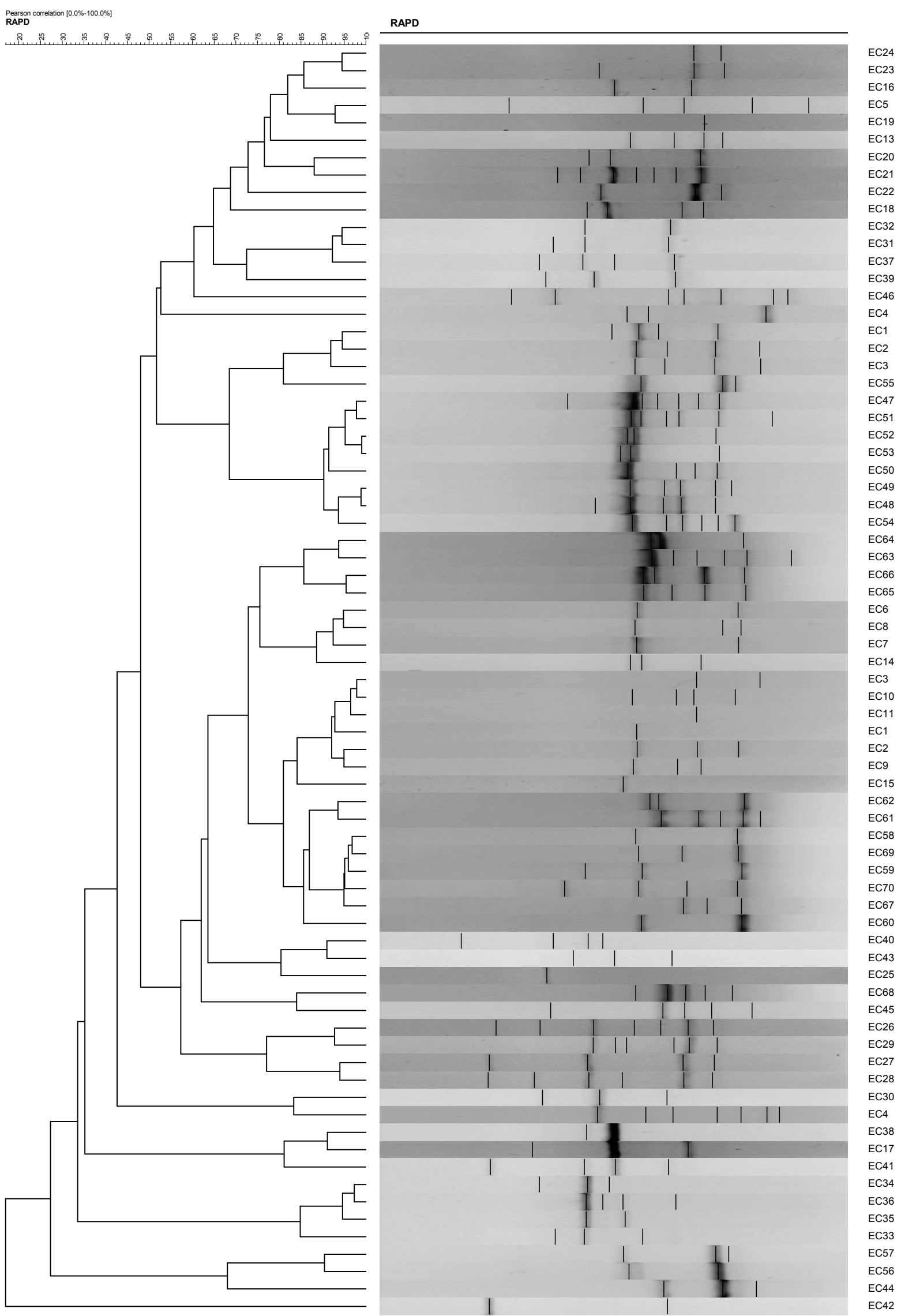

Figure 16. Dendogram of typable E.coli isolates from RAPD analysis (Gen 9) using average linkage unweighted group pair method with arithmetic average (UPGMA). 


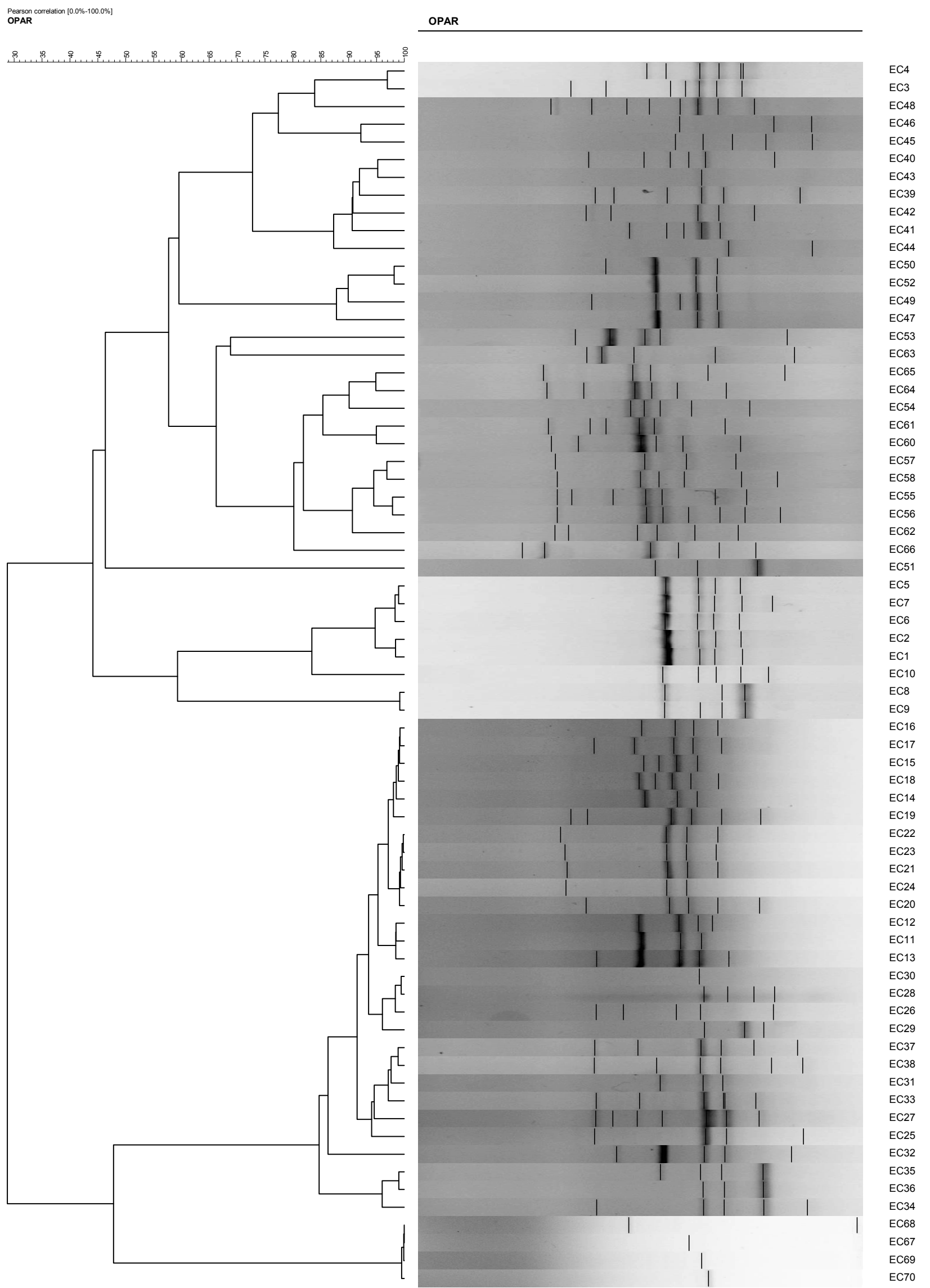

Figure 17. Dendogram of typable E. coli isolates from RAPD analysis (primer Opar 8) using average linkage unweighted group pair method with arithmetic average (UPGMA). 


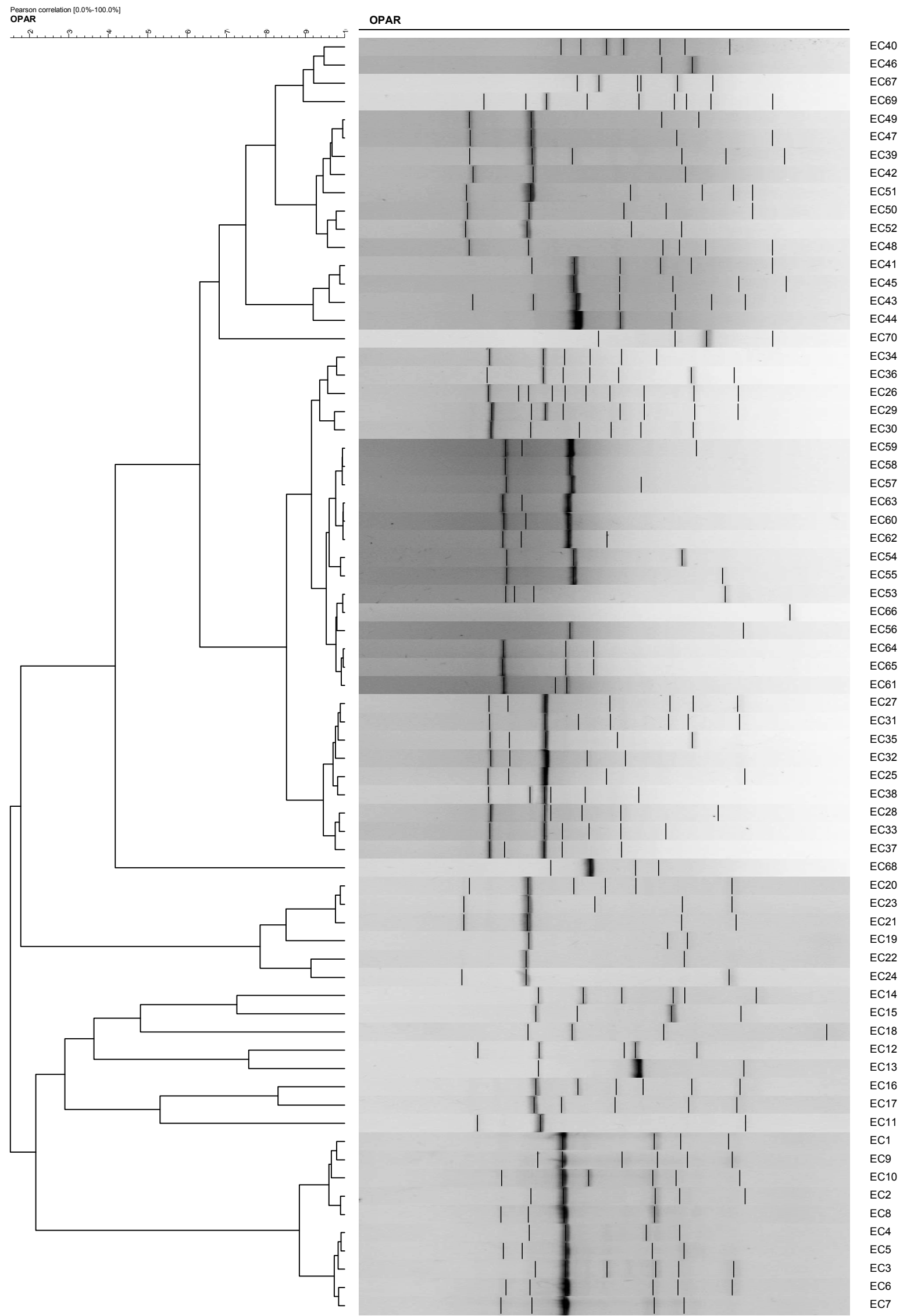

Figure 18. Dendogram of typable E. coli isolates from RAPD analysis (primer Opar 20) using average linkage unweighted group pair method with arithmetic average (UPGMA). 


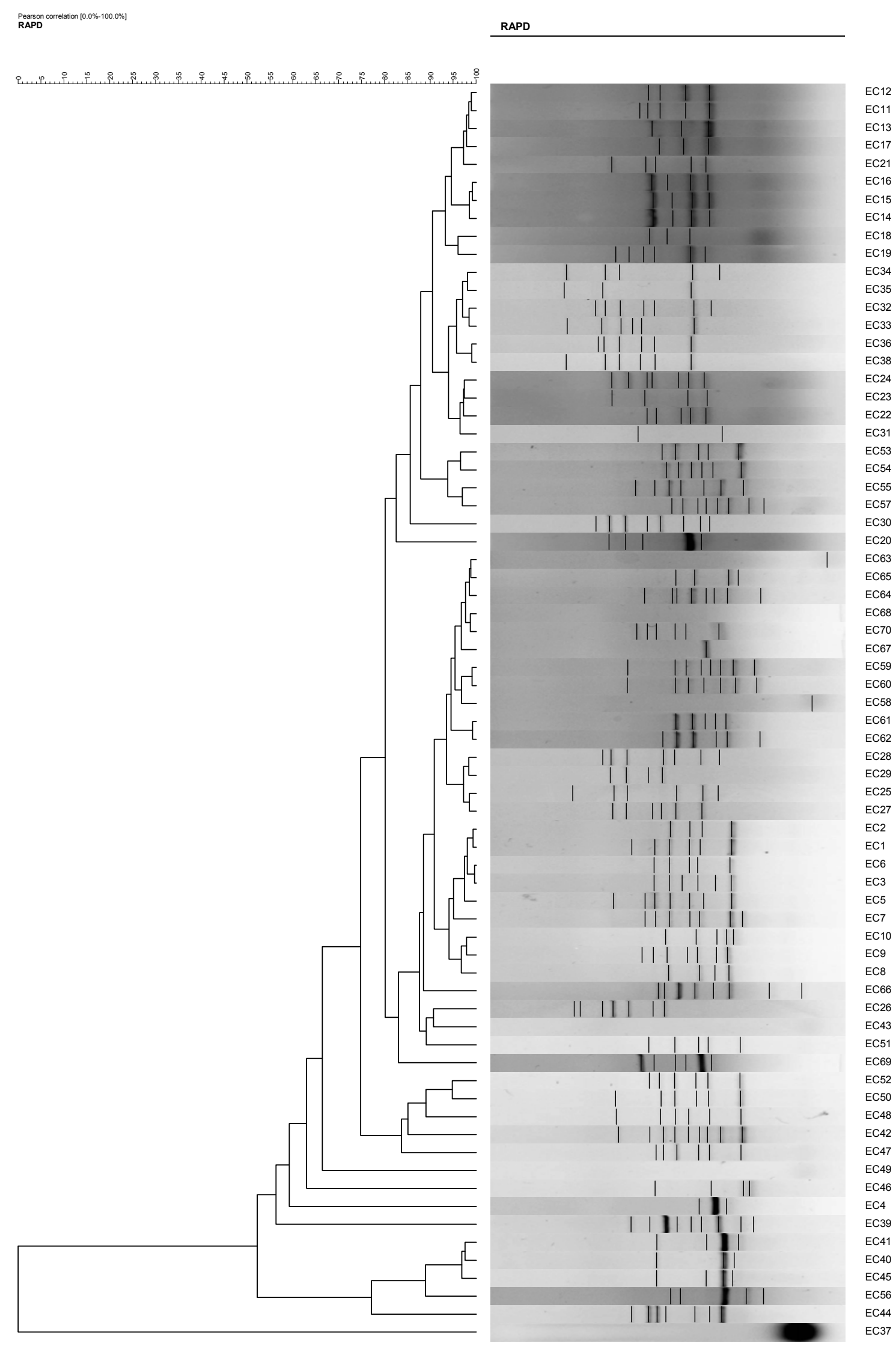

Figure 19. Dendogram of typable E. coli isolates from RAPD analysis (primer A1) using average linkage unweighted group pair method with arithmetic average (UPGMA). 


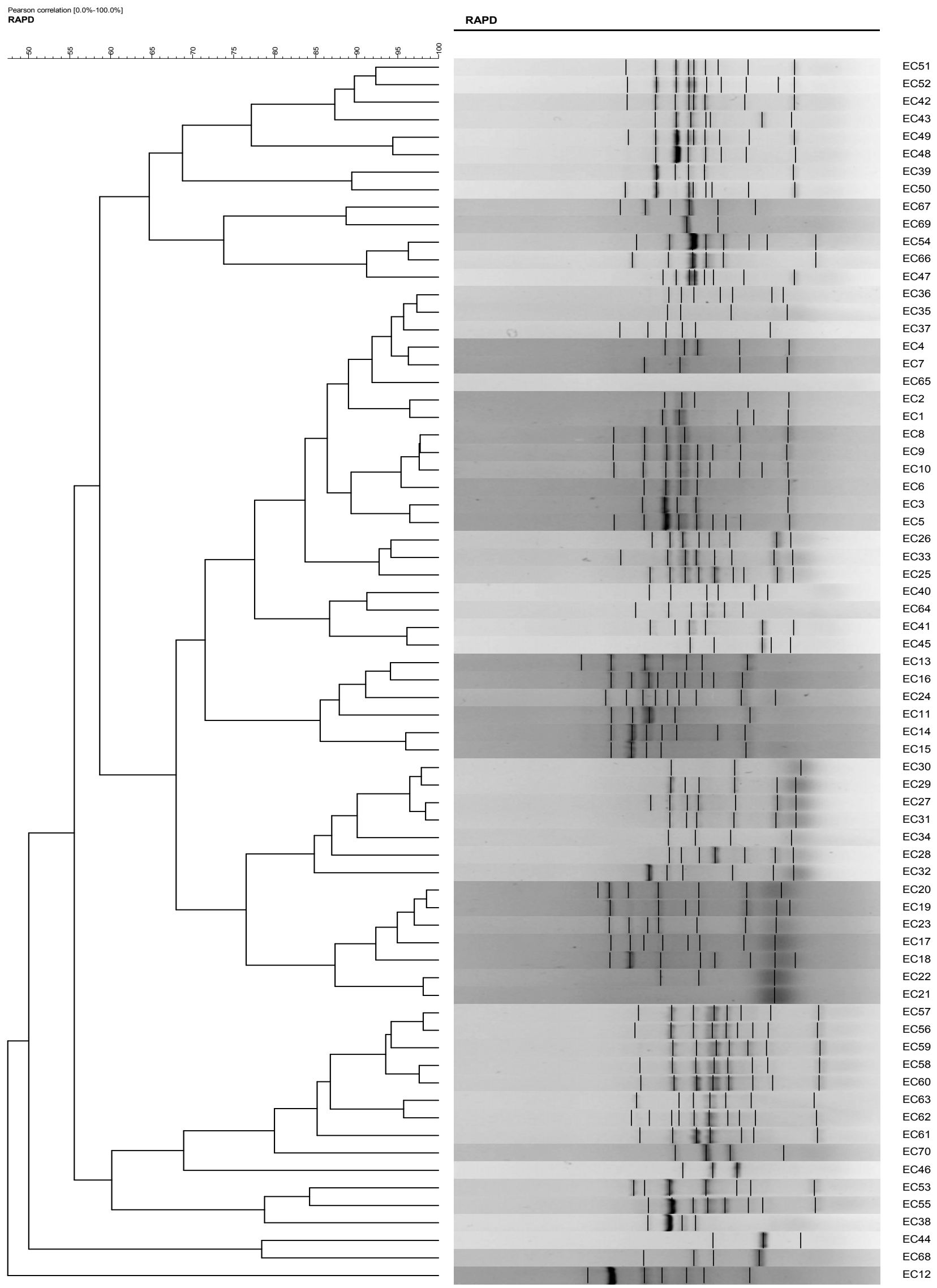

Figure 20. Dendogram of typable E.coli isolates from RAPD analysis (primer A7) using average linkage unweighted group pair method with arithmetic average (UPGMA). 
68 Abuelhassan Nawal Noureldaim et al:: Genetic Characterization of Shiga Toxin-producing Escherichia coli Strains Isolated from Imported Beef Meat in Malaysia Using Polymerase Chain Reaction Analysis

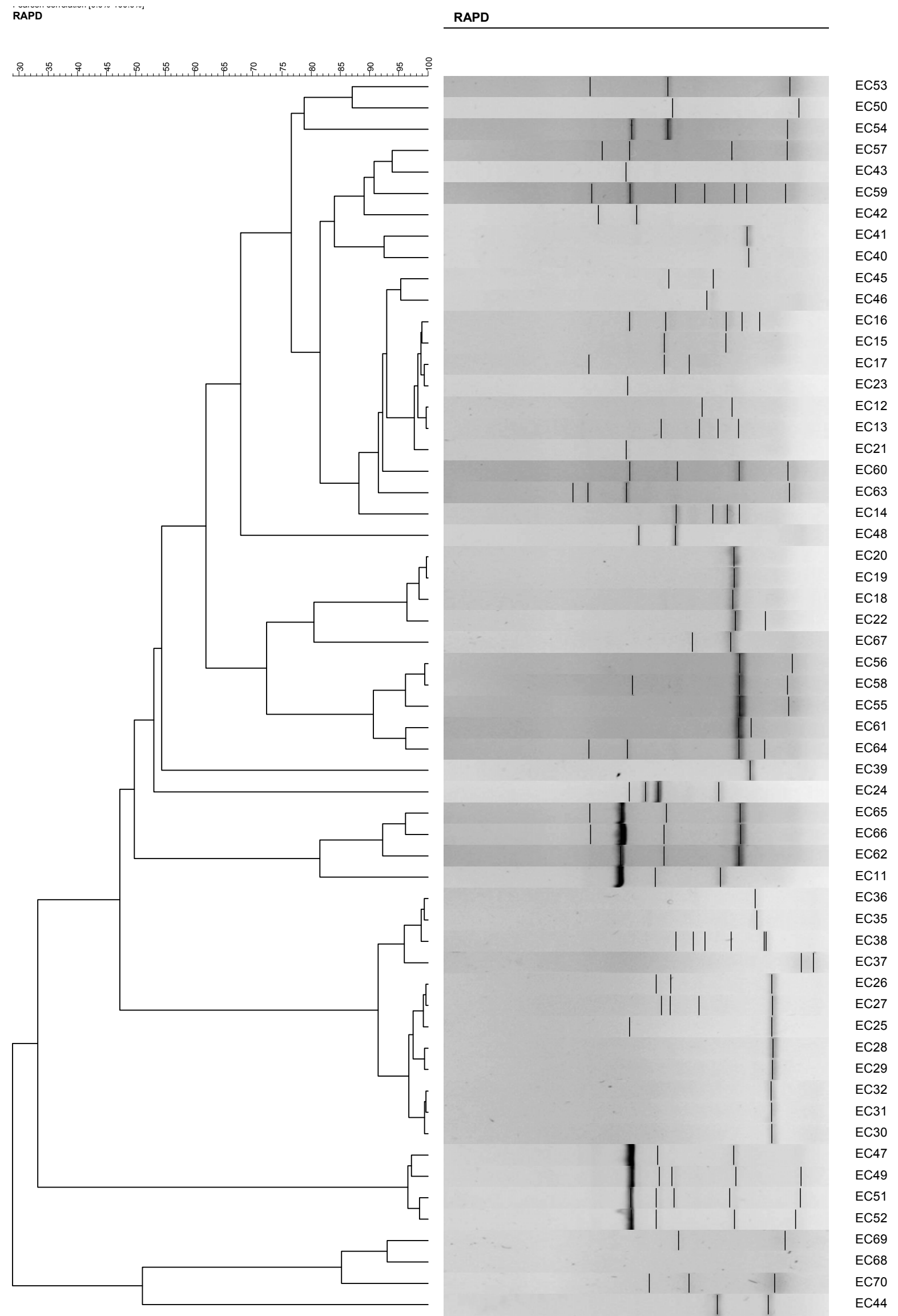

Figure 21. Dendogram of typable E.coli isolates from RAPD analysis (primer A10) using average linkage unweighted group pair method with arithmetic average (UPGMA). 


\section{Discussion}

In this work, the applications of the molecular typing technique, ERIC-PCR, and RAPD-PCR methods were used to subtype $E$. coli isolated from imported frozen meat sold in Malaysia hyper and super markets. Sixty two (62) isolates were found to harbor plasmid with size $23.2 \mathrm{~kb}$ while 43 isolates harbored more than a single plasmid. According to Kesava et al [30], profiling of plasmid is among the many valuable techniques to determine the relationship or nonrelationship of bacterial strains which consist of plasmid DNA, Isolates with single plasmids are mostly isolated from buffalo meat. Recently a work done by Kesava et al [30], comparable results were observed, in their study, it was observed that whereas the $21 \mathrm{~kb}$ plasmid was noticed in $23.3 \%$ (7) of shiga toxin producing E. coli and the smaller plasmids $3 \mathrm{~kb}$ and $2 \mathrm{~kb}$ plasmids were identified in $16.6 \%(5)$ of the isolates from beef.

Osaili et al [31], revealed that cows remain the major reservoirs of shiga toxin producing $E$. coli which may not show any clinical sign of the disease and the disease can cause ailment in human beings. Recently Osaili et al [31], in their work revealed that $7.8 \%$ of beef samples were found to be polluted with shiga toxin producing $E$. coli. In this work, occurrence of shiga toxin producing $E$. coli was considerably high comparing to the work done in South Africa that shows the rate of rate of shiga toxin producing $E$. coli to be $74.5 \%$ $[24,32]$. Both the genotypical and phenotypical methods revealed a varied heterogeneity amongst imported beef isolates of E. coli. Our result which shows the occurrence of shiga-toxin producing $E$. coli is rather disturbing and ought to draw a level of interest of the public health authorities of possible danger from imported beef meats.

Incidence and incidences of shiga-toxin producing $E$. coli have been investigated in raw meats in diverse region of the globe. Recently a work done in Egypt by Ahmed and Shimamoto [33], revealed that $3.4 \%$ of the samples of raw meat were positive of shiga-toxin producing $E$. coli out of the total 800 meat sample tested. Likewise, in Saudi Arabia $11.33 \%$ were positive for shiga-toxin producing $E$. coli out of the total 150 raw meats samples examined [34]. Hessain et al [35] also revealed that $2 \%$ of the total 200 raw meat samples examined were positive of shiga-toxin producing E. coli. Though, biochemical examinations are not sufficient in confirming isolates as E. coli; hence genotypic approaches of Random amplified polymorphic DNA-polymerase PCR (RAPD-PCR), Enterobacterial repetitive intergenic consensus-PCR (ERIC-PCR) and plasmid profiling are very important in confirming the biochemical test.

The outcome of the ERIC (Figures 3 and 4), RAPD-PCR (Figures 5 and 6) were analyzed using Gel Compare 11 software. RAPD-PCR analysis depends on the DNA polymorphisms within E. coli strains which are amplified during PCR procedure producing DNA fingerprints of different dimensions for differentiation purpose. According to Sahilah [16], application of DNA-based techniques in examining genetic relatedness of $E$. coli could aid in elucidating the epidemiology of STEC and EHEC isolates from different sources. The precise determinations of clones of $E$. coli are significant in the study of human epidemiologic outbreaks of STEC or EHEC. The method has been utilized successfully in determining the genetic similarity and epidemiological studies of E. coli. Recently, Sahilah et al [16] used the method to show the occurrence of varied heterogeneity within eggs and beef meat isolates of $E$. coli. Salehi et al. [36] used this technique for genetic differentiation of $E$. coli isolated from chicken. It has also been used to study epidemiology of $E$. coli isolated from human and animal feces [37]. The various genotypic patterns obtained in this studies based on the different genes used are as shown in Table 4. The patterns were obtained based on 7 genes analyzed. In this study, not all the isolates used were typeable using ERIC primers. Different detection pattern was observed among the RAPD primers used in this study. Five isolates $(31,37,43,58$ and 63$)$ were not detected by primer A1. A7 primer could not detect 2 isolates (21 and 65) (Table 4). However, primer A10 could not detect the highest number of the isolates $(4,10,12,33,37,45$ and 68) compared to other primers. Gene 8 primer could not detect (ND) with 3 isolates (11, 12 and 26), Gene 9 could not detect 3 isolates (31, 33 and 40) likewise; Opar 8 could not detect 5 isolates $(28,30,58,67$ and 70$)$. Whereas Opar 20 (55 and 62) could not detect two isolates (Table 4), gel picture are not shown. Therefore, primer may not be good for genetic relatedness study of $E$. coli isolated from imported beef and also may not be useful for epidemiological study. The highest pattern was observed in A7 gene. Gene 9 has the lowest genotyping of the isolates while Gene 8 has 58 genotypes, A1 (56), Opar 20 (55) and Opar 8 (54). Based on the results in this study, ERIC PCR profiled the isolates into 64. Hence, ERIC PCR discriminated the isolates better than RAPD.

From our result, there was no specific order and clustering that will be associated to $E$. coli within the different source of the samples and also in the different shops or location of sample purchase using all the three technique (ERIC and RAPD -PCR), this shows a very wide heterogeneity of $E$. coli isolate within and without. It also shows that isolate of $E$. coli from different countries and location could be similar and isolate from the same country or location could be quietly different. The $E$. coli isolate in this study exhibit a level of genetic variation which was very clear using all the two technique (ERIC and RAPDPCR), the RAPD-PCR revealed different amplification products leading to a configuration of bands usually from three to fifteen, with the size ranging from $200 \mathrm{bp}$ and $3 \mathrm{k}$ $\mathrm{bp}$. The strength of the different band is not consistent; nevertheless both the size and strength of every band can be reproduced using similar situation. According to Yang et al [38], RAPD-PCR genotyping method has the leads because of the less labor-intensiveness involve in the procedure, is also fast to completing the process and the methods is based on nucleotide sequence differences in the whole genome. 
Numerous molecular method of typing for example pulsedfield gel electrophoresis (PFGE), enterobacterial repetitive intergenic consensus sequence PCR (ERIC-PCR) ribosomal gene spacer sequence PCR (RS-PCR) and repetitive extragenic palindromic sequence PCR (REP-PCR) have been reported to subspecies differentiation of bacteria globally which could assist epidemiological investigations during disease outbreaks. RAPD molecular fingerprinting analysis was used in this study to principally understand the molecular relatedness of shiga toxin producing E. coli isolated from beef meats imported and sold in Malaysia from two major countries. In order to increase the reproducibility of RAPD analysis, 6 primers were used in this study. The discriminatory power (D-value) of this RAPD fingerprinting assay was 0.85 . This was in support of the method of [39] who investigated molecular characterization of E. coli 0157: H7. According to Maurer et al [40], RAPD show higher genetic variances amongst avian E. coli strains than other molecular typing methods for example restriction fragment length polymorphism (RFLP) analysis. Similarly, Ji-Yeon Kim et al. [39] state that RAPD analysis used in this study has advantages of less time consuming or laborious, cost-effective, sensitive, and no distinctive talents needed to do it.

Table 4. Molecular typing of E. coli (producing shiga toxin).

\begin{tabular}{|c|c|c|c|c|c|c|c|c|c|c|c|}
\hline \multirow{2}{*}{$\begin{array}{l}\text { Strain } \\
\text { No. }\end{array}$} & \multicolumn{2}{|c|}{ Shiga toxin } & \multirow{2}{*}{ ERIC profile } & \multicolumn{7}{|c|}{ RAPD Profile using different primers } & \multirow{2}{*}{ Genome type } \\
\hline & Stx $_{1}$ & Stx $_{2}$ & & Gene 8 & Gene 9 & Opar8 & Opar 20 & A1 & A7 & A10 & \\
\hline 1 & & & E1 & A1 & B1 & $\mathrm{C} 1$ & D1 & F1 & G1 & H1 & 1 \\
\hline 2 & & & E2 & $\mathrm{A} 1$ & $\mathrm{~B} 2$ & $\mathrm{C} 1$ & D1 & $\mathrm{F} 1$ & $\mathrm{G} 2$ & $\mathrm{H} 1$ & 2 \\
\hline 3 & & & E3 & $\mathrm{A} 1$ & $\mathrm{~B} 2$ & $\mathrm{C} 2$ & $\mathrm{D} 2$ & F2 & G3 & $\mathrm{H} 2$ & 3 \\
\hline 4 & & & E4 & $\mathrm{A} 2$ & B3 & $\mathrm{C} 3$ & D3 & F3 & G4 & ND & 4 \\
\hline 5 & & & E5 & $\mathrm{A} 3$ & B3 & $\mathrm{C} 4$ & D4 & F4 & G5 & $\mathrm{H} 3$ & 5 \\
\hline 6 & & & E6 & $\mathrm{A} 4$ & B4 & $\mathrm{C} 4$ & D5 & F5 & G6 & $\mathrm{H} 3$ & 6 \\
\hline 7 & & & E7 & A4 & B5 & $\mathrm{C} 5$ & D6 & F6 & G7 & $\mathrm{H} 4$ & 7 \\
\hline 8 & & & E8 & A5 & B6 & C6 & D7 & F7 & G8 & H5 & 8 \\
\hline 9 & & & E8 & A5 & B7 & C6 & D8 & F7 & G9 & H5 & 9 \\
\hline 10 & & & E8 & A6 & B8 & C7 & D9 & F8 & G10 & ND & 10 \\
\hline 11 & & & E9 & ND & B9 & $\mathrm{C} 8$ & D10 & F9 & G11 & H6 & 11 \\
\hline 12 & & & E10 & ND & B9 & C8 & D11 & F10 & G12 & ND & 12 \\
\hline 13 & & & E11 & A7 & B9 & C9 & D12 & F11 & G12 & H7 & 13 \\
\hline 14 & & & E12 & A8 & B10 & $\mathrm{C} 10$ & D13 & $\mathrm{F} 12$ & G13 & $\mathrm{H} 8$ & 14 \\
\hline 15 & & & E13 & A9 & B11 & C11 & D14 & F12 & G13 & H9 & 15 \\
\hline 16 & & & E14 & $\mathrm{A} 10$ & B12 & $\mathrm{C} 12$ & D15 & F12 & G13 & $\mathrm{H} 10$ & 16 \\
\hline 17 & & & E15 & A11 & B12 & $\mathrm{C} 13$ & D16 & F13 & G14 & H11 & 17 \\
\hline 18 & & & E16 & ND & B13 & $\mathrm{C} 14$ & D17 & F14 & G15 & H12 & 18 \\
\hline 19 & & & E17 & $\mathrm{A} 12$ & B14 & C15 & D18 & F15 & G16 & H13 & 19 \\
\hline 20 & & & ND & $\mathrm{A} 13$ & B15 & $\mathrm{C} 15$ & D19 & F16 & G16 & H14 & 20 \\
\hline 21 & & & E18 & A14 & B15 & $\mathrm{C} 16$ & D20 & F17 & ND & H15 & 21 \\
\hline 22 & & & E18 & A15 & B15 & $\mathrm{C} 16$ & D20 & F17 & G17 & H16 & 22 \\
\hline 23 & & & E19 & A16 & B15 & $\mathrm{C} 16$ & D21 & F19 & G18 & H17 & 23 \\
\hline 24 & & & E20 & A17 & B16 & $\mathrm{C} 16$ & D21 & F20 & G19 & H18 & 24 \\
\hline 25 & & & E21 & A18 & B17 & $\mathrm{C} 17$ & D22 & F21 & G20 & H19 & 25 \\
\hline 26 & & & E22 & ND & B17 & $\mathrm{C} 18$ & D23 & F22 & G21 & H19 & 26 \\
\hline 27 & & & E23 & A18 & B17 & $\mathrm{C} 19$ & D24 & F23 & $\mathrm{G} 22$ & H19 & 27 \\
\hline 28 & & & E24 & A19 & B18 & ND & D25 & F24 & $\mathrm{G} 23$ & H19 & 28 \\
\hline 29 & & & E25 & $\mathrm{A} 20$ & B18 & $\mathrm{C} 20$ & D25 & F25 & G24 & H19 & 29 \\
\hline 30 & & & E26 & $\mathrm{A} 21$ & B19 & ND & D26 & F26 & G25 & H19 & 30 \\
\hline 31 & & & E27 & A22 & ND & $\mathrm{C} 21$ & D27 & ND & G26 & H19 & 31 \\
\hline 32 & & & E28 & A23 & B20 & $\mathrm{C} 22$ & D28 & F27 & G27 & H19 & 32 \\
\hline 33 & & & E29 & A24 & ND & $\mathrm{C} 23$ & D29 & F28 & G28 & ND & 33 \\
\hline 34 & & & E30 & A25 & B20 & $\mathrm{C} 24$ & D29 & F29 & G29 & $\mathrm{H} 20$ & 34 \\
\hline 35 & & & E31 & A26 & B20 & $\mathrm{C} 25$ & D30 & F30 & G30 & $\mathrm{H} 21$ & 35 \\
\hline 36 & & & E32 & A27 & B21 & $\mathrm{C} 26$ & D31 & F31 & G31 & $\mathrm{H} 22$ & 36 \\
\hline 37 & & & E33 & A28 & B22 & $\mathrm{C} 27$ & D32 & ND & G32 & ND & 37 \\
\hline 38 & & & E34 & A29 & B23 & $\mathrm{C} 27$ & D33 & F32 & G33 & $\mathrm{H} 23$ & 38 \\
\hline 39 & & & E35 & $\mathrm{A} 30$ & B24 & $\mathrm{C} 28$ & D34 & F33 & G34 & $\mathrm{H} 24$ & 39 \\
\hline 40 & & & E36 & A31 & ND & $\mathrm{C} 29$ & D35 & F34 & G35 & $\mathrm{H} 24$ & 40 \\
\hline 41 & & & E37 & A32 & B25 & C30 & D36 & F34 & G36 & $\mathrm{H} 25$ & 41 \\
\hline 42 & & & E38 & A32 & B26 & $\mathrm{C} 31$ & D37 & F35 & G37 & $\mathrm{H} 26$ & 42 \\
\hline 43 & & & E39 & A33 & B26 & C32 & D38 & ND & G38 & $\mathrm{H} 27$ & 43 \\
\hline 45 & & & E41 & A35 & B28 & C34 & D40 & F37 & G40 & ND & 45 \\
\hline 46 & & & E42 & A36 & B29 & C35 & D41 & F38 & G41 & $\mathrm{H} 29$ & 46 \\
\hline 47 & & & E43 & A37 & B31 & C36 & D42 & F39 & G42 & $\mathrm{H} 30$ & 47 \\
\hline 48 & & & E44 & A38 & B31 & C36 & D43 & F40 & G43 & H31 & 48 \\
\hline 49 & & & E45 & $\mathrm{A} 38$ & B31 & C 37 & D43 & ND & G44 & $\mathrm{H} 32$ & 49 \\
\hline 50 & & & E46 & A39 & B32 & C38 & D44 & F41 & G45 & H32 & 50 \\
\hline 51 & & & E47 & $\mathrm{A} 40$ & B33 & C39 & D45 & F42 & G46 & H33 & 51 \\
\hline
\end{tabular}




\begin{tabular}{|c|c|c|c|c|c|c|c|c|c|c|c|}
\hline \multirow{2}{*}{$\begin{array}{l}\text { Strain } \\
\text { No. }\end{array}$} & \multicolumn{2}{|c|}{ Shiga toxin } & \multirow{2}{*}{ ERIC profile } & \multicolumn{7}{|c|}{ RAPD Profile using different primers } & \multirow{2}{*}{ Genome type } \\
\hline & Stx $_{1}$ & $\mathbf{S t x}_{2}$ & & Gene 8 & Gene 9 & Opar8 & Opar 20 & A1 & A7 & A10 & \\
\hline 52 & & & E48 & A41 & B33 & $\mathrm{C} 40$ & D46 & F43 & G46 & $\mathrm{H} 34$ & 52 \\
\hline 53 & & & E49 & A42 & B33 & $\mathrm{C} 41$ & D47 & F44 & G47 & H35 & 53 \\
\hline 54 & & & E50 & A43 & B34 & $\mathrm{C} 42$ & D48 & F45 & G48 & H36 & 54 \\
\hline 55 & & & E51 & A44 & B35 & $\mathrm{C} 43$ & ND & F46 & G49 & H37 & 55 \\
\hline 56 & & & E52 & A45 & B36 & $\mathrm{C} 44$ & D49 & F47 & G49 & $\mathrm{H} 38$ & 56 \\
\hline 57 & & & E53 & A46 & B37 & $\mathrm{C} 45$ & D50 & F48 & G49 & H39 & 57 \\
\hline 58 & & & E54 & A47 & B38 & ND & D50 & ND & G49 & H39 & 58 \\
\hline 59 & & & E55 & A48 & B38 & C46 & D50 & F48 & G50 & $\mathrm{H} 40$ & 59 \\
\hline 60 & & & E55 & A49 & B38 & C47 & D50 & F48 & G51 & $\mathrm{H} 40$ & 60 \\
\hline 61 & & & E56 & A50 & B39 & $\mathrm{C} 48$ & D50 & F48 & G52 & $\mathrm{H} 41$ & 61 \\
\hline 62 & & & E56 & A51 & B40 & C49 & ND & F49 & G53 & $\mathrm{H} 42$ & 62 \\
\hline 63 & & & E57 & A52 & B41 & C50 & D50 & ND & G54 & $\mathrm{H} 43$ & 63 \\
\hline 64 & & & E58 & A53 & B41 & C51 & D50 & F50 & G55 & H44 & 64 \\
\hline 65 & & & E59 & A54 & B42 & C51 & D51 & F51 & ND & $\mathrm{H} 45$ & 65 \\
\hline 66 & & & E60 & A54 & B43 & C52 & D51 & F52 & G56 & $\mathrm{H} 45$ & 66 \\
\hline 67 & & & E61 & A55 & B44 & ND & D52 & F53 & G57 & $\mathrm{H} 46$ & 67 \\
\hline 68 & & & E62 & A56 & B45 & C53 & D53 & F54 & G58 & ND & 68 \\
\hline 69 & & & E63 & A57 & B46 & C54 & D54 & F55 & G59 & $\mathrm{H} 47$ & 69 \\
\hline 70 & & & E64 & A58 & B47 & ND & D55 & F56 & G60 & $\mathrm{H} 48$ & 70 \\
\hline Total & & & 64 & 58 & 47 & 54 & 55 & 56 & 60 & 48 & 70 \\
\hline
\end{tabular}

NOTE: Gene $8=+\mathrm{A}$, Gene $9=\mathrm{B}$, Opar $8=\mathrm{C}$, Opar $20=\mathrm{D}, \mathrm{A} 1=\mathrm{F}, \mathrm{A} 7=\mathrm{G}, \mathrm{A} 10=\mathrm{H}, \mathrm{ERIC}=\mathrm{E}$ and ND $=$ Not detected.

\section{Conclusion}

In conclusion cows remain the major reservoirs of shiga toxin producing $E$. coli which may not show any clinical sign of the disease and the disease can cause ailment in human beings. ERIC PCR profiled the isolates into 64 in this study. Hence, ERIC PCR discriminated the isolates better than RAPD. There was no specific order and clustering that will be associated to $E$. coli within the different source of the samples and also in the different shops or location of sample purchase using all the three technique (ERIC and RAPD -PCR) in this study, this shows a very wide heterogeneity of $E$. coli isolate within and without.

\section{References}

[1] O'Hara, C. M. 2005. Manual and automated instrumentation for identification of Enterobacteriaceae and other aerobic gramnegative bacilli. Clinical Microbiology Reviews 18 (1): 147-162.

[2] Woo, P., Leung, P., Leung, K. \& Yuen, K. 2000. Identification by $16 \mathrm{~S}$ ribosomal RNA gene sequencing of an Enterobacteriaceae species from a bone marrow transplant recipient. Molecular pathology 53 (4): 211.

[3] Patel, J. B. 2001. 16S rRNA gene sequencing for bacterial pathogen identification in the clinical laboratory. Molecular Diagnosis 6 (4): 313-321.

[4] Woo, P., Lau, S., Teng, J., Tse, H. \& Yuen, K. Y. 2008. Then and now: use of $16 \mathrm{~S}$ rDNA gene sequencing for bacterial identification and discovery of novel bacteria in clinical microbiology laboratories. Clinical Microbiology and Infection 14 (10): 908-934.

[5] Lim, J. Y., Yoon, J. W. \& Hovde, C. J. 2010. A brief overview of Escherichia coli O157: H7 and its plasmid O157. Journal of microbiology and biotechnology 20 (1): 5.
[6] Zaidi, N., Konstantinou, K. \& Zervos, M. 2003. The role of molecular biology and nucleic Acid technology in the study of human infection and epidemiology. Archives of pathology \& laboratory medicine 127 (9): 1098-1105.

[7] Cheah, Y., Tay, L., Aida, A., Son, R., Nakaguchi, T. \& Nishibuchi, M. 2015. Molecular characterization of Escherichia coli isolated from different food sources. International Food Research Journal 22 (1): 31-40.

[8] Hulton, C., Higgins, C. \& Sharp, P. 1991. ERIC sequences: a novel family of repetitive elements in the genomes of Escherichia coli, Salmonella typhimurium and other enterobacteria. Molecular Microbiology 5 (4): 825-834.

[9] Versalovic, J., Koeuth, T. \& Lupski, R. 1991. Distribution of repetitive DNA sequences in eubacteria and application to finerpriting of bacterial enomes. Nucleic Acids Research 19 (24): 6823-6831.

[10] Wolska, K. \& Szweda, P. 2008. A comparative evaluation of PCR ribotyping and ERIC-PCR for determining the diversity of clinical Pseudomonas aeruginosa isolates. Pol J Microbiol 57 (2): 157-163.

[11] Dalla-Costa, L. M., Irino, K., Rodrigues, J., Rivera, I. N. \& Trabulsi, L. 1998. Characterisation of diarrhoeagenic Escherichia coli clones by ribotyping and ERIC-PCR. Journal of Medical Microbiology 47 (3): 227-234.

[12] Franklin, R. B., Taylor, D. R. \& Mills, A. L. 1999. Characterization of microbial communities using randomly amplified polymorphic DNA (RAPD). Journal of Microbiological Methods 35 (3): 225-235.

[13] Makino, S.-i., Okada, Y., Maruyama, T., Kaneko, S. \& Sasakawa, C. 1994. PCR-based random amplified polymorphic DNA fingerprinting of Yersinia pseudotuberculosis and its practical applications. Journal of Clinical Microbiology 32 (1): 65-69.

[14] Winget, D. M., Wommack, K. E., 2008. Randomly Amplified Polymorphic DNA PCR as a Tool for Assessment of Marine Viral Richness. Appl. Environ. Microbiol. 74, 2612-2618. 
[15] Radu, S., Ling, O. W., Rusul, G., Karim, M. I. A., Nishibuchi, M., 2001. Detection of Escherichia coli O157: H7 by multiplex PCR and their characterization by plasmid profiling, antimicrobial resistance, RAPD and PFGE analyses. J. Microbiol. Methods 46, 131-139.

[16] Sahilah, Audrey, L. Y. Y., Ong, S. L., Wan Sakeenah, W. N., Safiyyah, S., Norrakiah, A. S., Aminah, A. \& Ahmad Azuhairi, A. 2010. DNA profiling among egg and beef meat isolates of Escherichia coli by enterobacterial repetitive intergenic consensus-PCR (ERIC-PCR) and random amplified polymorphic DNA-PCR (RAPD-PCR). International Food Research Journal 17 (4): 853-866.

[17] Law, D. 2000. Virulence factors of Escherichia coli O157 and other Shiga toxin-producing E. coli. Journal of Applied Microbiology 88 (5): 729-745.

[18] Etcheverría, A. I. \& Padola, N. L. 2013. Shiga toxinproducing Escherichia coli: Factors involved in virulence and cattle colonization. Virulence 4 (5): 366-372.

[19] Karmali, M. A., Gannon, V. \& Sargeant, J. M. 2010. Verocytotoxin-producing Escherichia coli (VTEC). Veterinary Microbiology 140 (3-4): 360-370.

[20] Scheutz, F., Teel, L. D., Beutin, L., Piérard, D., Buvens, G., Karch, H., Mellmann, A., Caprioli, A., Tozzoli, R., Morabito, S., Strockbine, N. A., Melton-Celsa, A. R., Sanchez, M., Persson, S. \& O'Brien, A. D. 2012. Multicenter Evaluation of a Sequence-Based Protocol for Subtyping Shiga Toxins and Standardizing Stx Nomenclature. Journal of Clinical Microbiology 50 (9): 2951-2963.

[21] Gyles, C. 2007. Shiga toxin-producing Escherichia coli: an overview. Journal of Animal Science 85 (13 Suppl): E45-62.

[22] Radu, S., Mutalib, S. A., Rusul, G., Ahmad, Z., Morigaki, T., Asai, N., Kim, Y. B., Okuda, J. \& Nishibuchi, M. 1998. Detection of Escherichia coli O157: H7 in the Beef Marketed in Malaysia. Applied and Environmental Microbiology 64 (3): 1153-1156.

[23] Charimba, G., Hugo, C., Hugo, A., 2012. The incidence of diarrhoeagenic Escherichia coli in minced beef and boerewors. Food Research International 47, 353-358.

[24] Jothikumar, N. \& Griffiths, M. W. 2002. Rapid detection of Escherichia coli O157: H7 with multiplex real-time PCR assays. Applied and Environmental Microbiology 68 (6): 3169-3171.

[25] Li, M. C., Wang, F., Li, F., 2011. Identification and molecular characterization of antimicrobial-resistant shiga toxinproducing Escherichia coli isolated from retail meat products. Foodborne pathogens and disease 8, 489-493.

[26] Italia, J. T., Rovira, H. G., Masangkay, J. S., Yoshikawa, Y., Perez, M. T. M., Reyes, A. W. B., Baticados, W. N., 2012. Conventional isolation and polymerase chain reaction for detection of Escherichia coli O157: H7 from intestines of Philippine bats. Veterinarski Arhiv 82, 283-294.

[27] Wang, Y., Leung, P., Qian, P.-Y., Gu, J.-D., 2006. Antibiotic resistance and plasmid profile of environmental isolates of Vibrio species from Mai Po Nature Reserve, Hong Kong. Ecotoxicology 15, 371-378.

[28] Lesley, M., Velnetti, L., Cheah, Y., Son, R., Kasing, A., Samuel, L., Micky, V., Nishibuchi, M., 2011. Antibiotic resistance and plasmid profiling of Vibrio parahaemolyticus isolated from cockles (Anadara granosa) at Tanjung Karang, Kuala Selangor. Int. F. Res. J. 18.

[29] Devi, R., Surendran, P., Chakraborty, K., 2009. Antibiotic resistance and plasmid profiling of Vibrio parahaemolyticus isolated from shrimp farms along the southwest coast of India. World Journal of Microbiology and Biotechnology 25, 20052012.

[30] Kesava, N., Rajendra, G., Gaddad, S., Shivannavar, C., 2011. Detection of shiga toxin genes (stx1 \& stx2) and molecular characterization of shiga-toxigenic Escherichia coli isolated from diverse sources in gulbarga region, India. Pharmacophore 2, 253-265.

[31] Osaili, T. M., Alaboudi, A. R., Rahahlah, M., 2013. Prevalence and antimicrobial susceptibility of Escherichia coli O157: H7 on beef cattle slaughtered in Amman abattoir. Meat Science 93, 463-468.

[32] Vorster, S., Greebe, R., Nortje, G., 1994. Incidence of Staphylococcus aureus and Escherichia coli in ground beef, broilers and processed meats in Pretoria, South Africa. Journal of Food Protection ${ }^{\circledR}$ 57, 305-310.

[33] Ahmed, A. M., Shimamoto, T., 2014. Isolation and molecular characterization of Salmonella enterica, Escherichia coli O157: H7 and Shigella spp. from meat and dairy products in Egypt. Int. J. Food Microbiol. 168-169, 57-62.

[34] Al-Zogibi, O. G., Mohamed, M. I., Hessain, A. M., El-Jakee, J. K., Kabli, S. A., 2015. Molecular and serotyping characterization of shiga toxogenic Escherichia coli associated with food collected from Saudi Arabia. Saudi Journal of Biological Sciences 22, 438-442.

[35] Hessain, A. M., Al-Arfaj, A. A., Zakri, A. M., El-Jakee, J. K. Al-Zogibi, O. G., Hemeg, H. A., Ibrahim, I. M., 2015. Molecular characterization of Escherichia coli O157: H7 recovered from meat and meat products relevant to human health in Riyadh, Saudi Arabia. Saudi Journal of Biological Sciences.

[36] Salehi, T. Z., Madani, S. A., Karimi, V., Khazaeli, F. A., 2008. Molecular genetic differentiation of avian Escherichia coli by RAPD-PCR. Braz. J. Microbiol. 39, 494-497.

[37] Venieri, D., Vantarakis, A., Komninou, G., Papapetropoulou, M., 2004. Differentiation of faecal Escherichia coli from human and animal sources by random amplified polymorphic DNA-PCR (RAPD-PCR). Water Sci. Technol. 50, 193-198.

[38] Yang, Z.-q., Jiao, X.-a., Zhou, X.-h., Cao, G.-x., Fang, W.-m., $\mathrm{Gu}$, R.-x., 2008. Isolation and molecular characterization of Vibrio parahaemolyticus from fresh, low-temperature preserved, dried, and salted seafood products in two coastal areas of eastern China. Int. J. Food Microbiol. 125, 279-285.

[39] Ji-Yeon Kim, So-Hyun Kim, Nam-Hoon Kwon, Won-Ki Bae, J.-Y. L., Hye-Cheong Koo,, Jun-Man Kim, K.-M. N., WooKyung Jung, Kun-Taek Park, Yong-Ho Park, 2003. Isolation and identification of Escherichia coli 0157: h7 using different detection methods and molecular determination by multiplex PCR and RAPD. Journal of veterinary science 6, 7-19.

[40] Maurer, J. J., Lee, M. D., Lobsinger, C., Brown, T., Maier, M., Thayer, S. G., 1998. Molecular typing of avian Escherichia coli isolates by random amplification of polymorphic DNA. Avian Dis., 431-451. 